\title{
Evaluating Tourism Market Regulation from Tourists' Perspective: Scale Development and Validation
}

\begin{abstract}
Despite the increasing attention given to tourism regulation in recent years, great ambiguity surrounds this concept and no valid and reliable instrument exists to measure tourism market regulation (TMR). This study uses multi-step mixed methods to develop a measurement scale of TMR from the perspective of tourists. In the first step, interviews and focus groups are undertaken to formulate a clear definition of TMR and its attributes. In the second step, a scale development procedure is adopted to analyze two rounds of data for dimension exploration via EFA and confirmation via CFA. Through these analyses, five dimensions are generated: regulatory oversight, truth in advertising, tourism contract compliance, fulfilling tourism contracts, and travel feedback processing. The reliable and valid results contribute to refining TMR in the context of China. They also provide a useful tool for tourists and destination marketing organizations to measure and govern TMR in other regions/countries. Keywords tourism market regulation; regulatory oversight; fulfilling tourism contract; travel feedback processing; scale development.
\end{abstract}




\section{Introduction}

In recent years, the tourism industry has developed rapidly in China. In 2018, the number of Chinese domestic tourist arrivals reached 5.53 billion, alongside 141.20 million inbound tourists, and generated a total income of RMB 5,970 billion, which was $10.5 \%$ higher than the total income in 2017 (MCT 2019). Employment opportunities increased directly and indirectly by the tourism industry account for $10.29 \%$ of the total employment in China (MCT 2019). Clearly, the tourism industry plays an important role in the Chinese economy. However, parasitic phenomena, such as zero-commission tours (Zhang, Heung, and Yan 2009; Zhang, Yan, and Li 2009), free-of-charge or even negative-charge tours (Fu 2010; He, and Cui 2006; Jia, Wei and Yang 2011), “ripping off” tourists (Harris 2012; Ling 2014), and unethical marketing practices (Cavicchi and Santini 2011; King, Dwyer, and Prideaux 2006; March 2008), are accompanying the booming development of tourism.

Such malpractices in China's tourism market are severely harmful to the consumers of tourism products and disturb the regulation of the tourism market as well as the sustainability of the tourism industry. This situation has drawn considerable attention among and criticism from the Chinese public. Every year after public holidays, disputes involving all kinds of tourism enterprises cause heated media and public debates. Tourism regulations include wide-ranging issues, such as tourism experience, environmental impacts, social cohesion, local culture, and livelihood of local residents. Tourism market regulation (TMR) has become a focus of concern in the society owing to the inconsistencies and abuse in the tourism market. The tourism industry is defined as a series of goods and services that depend on the tourism consumed by tourists (Frechtling 1999; Frechtling 2010; Smeral 2006). Systematically establishing a set of standards to assess the situation of market regulation from the perspective of tourists is fundamental to the protection of tourist rights and the preservation of the tourism industry's ethical integrity. 
Many countries and areas have established laws and regulations to regulate their tourism market (Grant 1996; March 2008; Zhang, Yan, and Li 2009). For instance, the European Commission (EC) Package Travel Regulations 1992 (SI 1992 No. 3288) launched clauses to protect consumers (Grant 1996). The European Parliament and the Council of the European Union (EU) composed Directive (EU) 2015/2302, which stipulates important consumer rights in relation to package travel and linked travel arrangements (The European Parliament and the Council of European Union 2015). Japan passed the Tourism Nation Promotion Basic Law, Travel Agent Law, and Hotel Law to create an environment conducive to travel. Australia created the Regulation of Travel Agents Act to promote fair terms of trading. Hong Kong enacted Travel Agent Ordinance and Travel Agents Regulations to control and regulate travel agents, including the Travel Industry Compensation Fund Rules, which provide consumers with a procedure for ex gratia payment and regulate the amount of ex gratia payment and financial penalty. Travel Industry Ordinance (No.37 of 2018) sets detailed regulations for the whole travel industry (Legislative Council of Hong Kong SAR 2018). Moreover, mainland China has laws and regulations that aim to protect tourists, such as the Tourism Law, Travel Agency Ordinance, Contract Law, Consumer Protection Law, Advertising Law, and Criminal Law.

The tourism system is a combination of intangible service products with tangible aspects. It has a reasonable number of laws and regulations to monitor tangible aspects of the industry, such as tourism service contracts, quality of products, and refund procedures. However, such laws and regulations have not effectively banned activities that disturb the intangible aspects of the tourism market, such as zero-commission tours that lead to forced shopping, overpricing, and implicit misleading advertising. Regulations for illegal and lawbreaking practices likewise exist, but unethical but lawful practices, such as price-cutting and unethical shopping practices, are difficult to monitor and regulate using existing authorized 
laws and regulations. These activities have great negative impacts on tourists' experiences and destination image (March 2008), easily drawing substantial attention and spreading negative word of mouth on social media. In addition, while existing tourism regulation studies emphasize the leading role of the destination government and service operators (Kohl and Greenlaw 1983; Qu, Ennew and Sinclair 2005; Thomas and Thomas 1992), the role and viewpoints of tourists, as service receivers, are largely overlooked in the consultation and execution stages.

Statistics show that tourism complaints in 2018 are categorized into six areas: aviation (24\%), hotels (29.92\%), travel agencies (27.88\%), tourism attractions (4.93\%), and tour guides (1.89\%) (The People's Daily 2019). The refund and change of ticket, inconsistency between travel contract and itinerary, forced shopping by tour leaders, and poor service attitude are the most frequent complaints (The People's Daily 2019). TMR is frequently referenced in tourism information and policies, but what exactly is TMR? What are its dimensions? How should it be evaluated considering unethical—rather than merely illegal— activities from the perspective of tourists? Despite the rapid growth of China's tourism market, no valid and reliable instrument is available to measure the situation of TMR. For the reasons discussed above, evaluating TMR has become an important issue for the tourism industry.

To fill the research gap, this study investigates TMR by defining the construct and developing a measurement scale. First, it uses an inductive approach to conceptualize TMR and specify its domain, as recommended by Hinkin, Tracey, and Enz (1997). Through qualitative methods, a theoretical framework and conceptualization of TMR are established by delineating its conceptual domain and highlighting its sub-components (Riefler, Diamantopoulos, and Siguaw 2012). The wording and content validity of TMR measurement items extracted from the literature review and qualitative research are assessed. Second, this 
study analyzes two rounds of quantitative data with exploratory factor analysis (EFA) and confirmatory factor analysis (CFA), respectively. The findings are then used to develop a multidimensional scale of TMR. Consequently, this study can enrich TMR research and provide a useful tool for the government and destination marketing organizations (DMOs) to measure and manage TMR from the perspective of tourists. 


\section{Literature Review}

\section{Market Regulation}

Scientific assessment of the situation of market regulation is the foundation to improve market regulation (Research Group on the Evaluation of Market Regulation 1998). To date, most research on market regulation adopts an economics perspective. Prominent contributions include spontaneous order theory, which is based on economic liberalism. Proposed by Hayek (1967), spontaneous order theory points out that market order is the result of irresistible spontaneous evolution rather than a process of top-down central planning or a well-organized design. According to Hayek's Sensory Order, market regulation can be perceived by consumers (Hayek 1952). Smith (1776) considered the "invisible hand" of price and competition mechanisms as the foundation of market regulation. Marx (1867) believed that market regulation is the evolution of society and history. Commons (1931) developed Marx's thought on market regulation by considering it as a state of collective action that controls individual actions.

Hong (2005) defined market regulation as market norms, institutions, and corresponding compliance. Regulation is generally accepted as consisting of authoritative rules issued by the state but pluralized in important ways (Drahos 2017). New institutional economics, as represented by Coase (2012) and North (1990), asserts that the formation and development of market regulation depend on the spontaneous evolution of the market and the intervention by the government supplying the applicable institutions. The government has three possible roles in different stages of economic development: active involvement, creating an "enabling environment" to support the development of the sector but not taking any commercial role, and benign neglect where it does not directly support but neither discriminate. Williamson (1996) and Powell (1990) further developed institutional economics and explored the mechanism of the network in the formation of market 
regulation. The literature clearly indicates that views on market regulation stem from the market economy.

\section{Tourism Market Regulation}

TMR is an important criterion for measuring the condition of regional tourism development (CNTA 2016). However, researchers have paid minimal attention to "regulatory theory" (Randle and Hoye 2016). Studies on TMR have mostly focused on specific events and social phenomena in the tourist market, such as assessing tourists' reactions to an unethical destination incident (Breitsohl and Garrod 2016). The phenomena of zero commission, "ripping off" tourists, and unethical marketing practices, all of which disrupt TMR, have gained more attention (Cavicchi and Santini 2011; Harris 2012; King et al. 2006; March 2008; Zhang, Heung, and Yan 2009). Zhang, Yan, and Li (2009) demystified the mechanism of zero-commission tours and analyzed factors causing this negative event. Zero-based activities have mainly been attributed to the government's failure to properly regulate (Kim and Gerber 2005).

According to the regulatory theory proposed by Baldwin, Cave, and Lodge (2011), the primary reason for regulation in most countries is consumer protection. For instance, the EC Package Travel Regulations 1992 (SI 1992 No. 3288) launched clauses for holidaymakers to be compensated for any breach of contract by the tour operator. The European Parliament and the Council of European Union amended Regulation (EC) No 2006/2004 and Directive 2011/83/EU and enacted Directive (EU) 2015/2302 on package travel and linked travel arrangements to contribute to the proper functioning of the internal market and a high level of consumer protection, particularly with regard to information requirements and the liability of traders (The European Parliament and the Council of European Union 2015). For over 15 years, the Hong Kong Tourism Board has promoted accredited "Quality Tourism Services" 
and resolved complaints from tourists to reinforce Hong Kong's image as a destination offering quality tourism services and products. In 2018 China amended its Tourism Law to protect the lawful rights and interests of tourists and tourism operators as well as regulate the order of the tourism market (Standing Committee of the National People's Congress 2018). Laws that do not mention tourism services specifically but certainly encompass all service offerings also exist, including the Constitution, civil and commercial laws such as the Contract Law, the Company Law, economic laws, the Criminal Law, and so on. China has issued a series of policy documents, including regulations that aim to rectify market order.

However, the existing government regulations do not cover the various services offered in China, such as zero-commission tours and unethical marketing practices. Partial laws are not adequate or implemented properly, such as the Tourism Law (Tang 2013). The main reasons for the illegal and unethical behaviors in China's tourism market are immaturity of the market environment, noncredit transactions of tourism enterprises, and an improper supervision and management system (Du 2012). The regulatory environment of a destination is an important dimension of TMR, and improved regulation can typically reduce the extent of unethical practices (March 2008). Another factor is the quality of tourism services, which is the source of tourist dissatisfaction and even outrage (Crotts, Pan, and Raschid 2008), such as tour guides "ripping off” tourists (Harris 2012; Ling 2014). As Mak, Wong, and Chang (2011) pointed out, the factors influencing the service quality of tour guides include unhealthy business practices of travel agencies, immaturity of the tourism market, unfair exploitative measures, and the assurance mechanism. Institutionalizing the protection of tourist rights should be an indispensable condition of the tourism development strategy (Viktorovna, Shamilevna, and Yurievna 2014).

With every country facing the challenge of sustainable development, effective regulatory plans are required (Drahos 2017). Prior to such plans, developing a tool that can 
evaluate the state of TMR is necessary. Many tourism associations and governments have their own codes of conduct to ensure members are protected by laws and regulations (Mak et al. 2011). Regulation poses challenges for commercial tourism. The three models of intervention in tourism development are central planning and control by the government, self-regulation by the tourism industry (Randle and Hoye 2016), and public-private partnerships taking charge of regulation (Huybers and Bennett 1997; Wilson, Nielsen, and Buultjens 2009). Laws, regulations, and state intervention can regulate illegal activities and law breaking. However, unethical but legal behaviors should be self-regulated by tourism enterprises or organizations. For example, the Association of British Travel Agents have a Code of Conduct and guidance on the application to self-regulate members for tourist protection; the Code governs areas such as accurate advertising changes to bookings and managing customer complaints (Association of British Travel Agents 2018). There are other self-regulatory organizations, such as National Tour Association, Japan Association of Travel Agents, and National Association of Travel Agents Singapore. China Tourism Association and China Association of Travel Services began to self-regulate independently after decoupling from the government in 2016 and 2017, respectively. Self-regulatory organizations may well develop codes of conduct for tourists and practitioners, but they do not make the laws of the land. Codes of conduct introduce ethical rather than legal parameters and cannot punish unethical but legal business behavior. Nevertheless, they identify approved behaviors and set up self-disciplines, which are effective supplements to legal regulation. Are all the regulatory plans above effective? What is the condition of TMR in a destination? What do tourists care most about when traveling? How can TMR be evaluated from the perspective of tourists? Tourists' role and viewpoints are fundamental to regulation making and implementation. Thus, a set of standards that can assess the situation of TMR must be systematically established. 
Strategies regulating commercial tourism from a stakeholder perspective have been found to be effective, which can increase the trust and support of stakeholders for government regulation (Randle and Hoye 2016). Meanwhile, the government needs to deliver the policy and planning framework. Hall (2012) stated that the government plays an important role in shaping the regulatory and policy structures that influence medical tourism. For instance, it can create an enabling environment by establishing supportive legislation or regulations that help tourism develop (Jenkins 2012). Through quality standards in tourism, health care, food, and housing, regulation can enhance tourists' wellbeing, provide consumer protection, and safeguard tourists' security and rights (Drahos, 2017). A scale must therefore be developed that considers illegal practices and unethical behaviors from the perspective of tourists. Although studies have been conducted on the economics paradigm of market regulation, these mainly concerned general commodity markets. TMR has unique characteristics that distinguish it from general commodity regulation because of its service and experiential nature. Therefore, additional focus on TMR is needed. 


\section{Methodology}

This study followed an eight-step procedure for developing the measurement scale proposed by Churchill (1979). The scale has been widely used in previous studies (e.g., DeVellis 2012; Ghosh and Mandal 2018; Hung and Petrick 2010; Yen, Tsaur, and Tsai 2018). Churchill (1979) proposed that researchers should demonstrate flexibility when applying his procedures (Zhang, Fan, Tse, and King 2016). In the present study, the eight steps involved are as follows. (1) Specify the domain of the construct: TMR is defined by precisely delineating which content is included and which is excluded (Churchill 1979). (2) Item generation: This step involves the initial items extracted from literature review and qualitative approach. Through literature review and content analysis of the in-depth interviews and focus group data as well as documents of relevant laws and policies, items were obtained across five dimensions. (3) Item purification and content validity: This study reviewed wording and content validity through a panel of experts to refine the measurement items. (4) Collect data: Data were collected through an online survey and offline fieldwork to prevent the systematic research bias that may result from data collection through a single channel. (5) Explore dimensionality: EFA was used to generate dimensions. (6) Collect data: Second-round data were also collected through an online survey and offline fieldwork. (7) Assess reliability: Reliability was assessed through coefficient alpha and composite reliability. (8) Confirm dimensionality: CFA was conducted to test the validity of the scale (Table 1).

\section{Table 1 here}

\section{Data Collection}

The qualitative data were collected through in-depth interviews and focus group, while the 
quantitative data were collected through an online panel survey covering 34 provincial-level administrative regions in China and an offline field survey in cities of Tianjin, Beijing, Shanghai, and Guangzhou. The entire data collection duration was September 2017 to September 2018. Following the multi-stage design outlined above, this study explored the conceptual construct of TMR, generated items, and then purified those items through face and content validity tests. The purified items were then displayed in detail in scale development. After these three steps, a questionnaire comprising 27 initial items was confirmed (Appendix A). To obtain a reliable and valid measurement scale, two rounds of data were collected before dimensionality was assessed through EFA and CFA.

In the questionnaire, tourists were asked to make an objective analysis of TMR on the basis of their latest travel experience. For tourists, it is to evaluate both the outcomes and process-based issues of TMR. Evaluating the outcomes of TMR is a difficult task for tourists. A screening question (“Have you had a travel experience in the past 12 months?") was designed to identify eligible respondents (Wang, Hung, and Li 2018). Only tourists who answered "Yes" were selected. The questionnaire comprised four parts: instructions to respondents, travel details, measurement items, and demographic questions. In the first part, the instructions explained the purpose of the survey and how to evaluate TMR. The second part comprised two multiple-choice questions asking respondents to identify the following: "The area where you traveled most recently" (possible answers included 34 provincial-level administrative regions in China and abroad) and "The type of tourism enterprises that recently provided you with products or services." The purpose of these questions was to guide respondents in completing the questionnaire basing on their latest travel experience. The third part collected data through items evaluating TMR. The last part collected the tourists' demographic information, following the approach in CNTA (2017).

The online survey was conducted by a survey company named Wenjuanxing 
(www.wjx.cn). The company was responsible for randomly distributing the questionnaire to tourists online. The offline fieldwork survey was conducted in tourist attractions and hotels with the assistance of travel agencies in China. Through sampling, a total of 500 questionnaires were distributed, 300 through the online survey and 200 through fieldwork from December 2017 to April 2018. In total, 415 valid questionnaires were obtained. The item ratio was 15.4:1, which is higher than the standard 10:1 recommended by Hair, Black, Babin, and Anderson (2010), Kline (2005) and Nunnally (1994). The second round of data for CFA was collected in the same way from May to September in 2018. Of the 400 questionnaires distributed, 319 valid questionnaires were returned.

\section{Data Analysis}

Qualitative research data were analyzed using content analysis following the approaches of Holsti (1968) and Strauss (1987). According to the data from the quantitative questionnaire, the first analytical step was data cleaning. This step was conducted by detecting invalid questionnaires with missing items, obvious inconsistencies, and clear signs that a respondent did not take the survey seriously, such as assigning the same value to all answers and missing data. Descriptive statistics, including means, standard deviations, skewness, and kurtosis, were used to test the normality of the data. Cronbach's alpha and item-total statistics were calculated to assess the reliability of the TMR scale. Data collected in the first round $(n=415)$ were analyzed by EFA to explore the dimensionality of the construct. To further validate the underlying structure and confirm the scale's dimensionality, the secondround data $(\mathrm{n}=319)$ were analyzed using CFA with AMOS 24.0. The composite reliability (CR), discriminant validity, nomological validity, and goodness-of-fit statistics of the model were statistically evaluated. 


\section{Scale Development}

\section{Study 1: Conceptualization}

\section{Specify the Construct Domain of TMR}

The first step for scale development is to specify the construct domain (Churchill 1979). When exploring a concept that is not clearly defined, an inductive approach is recommended (Hinkin et al. 1997). Therefore, a qualitative pre-study was undertaken to explore the conceptualization and basic dimensions of TMR using primary and secondary data. The secondary data included exploration in greater detail of the laws, policies and enforcement capabilities to determine whether there are regulations to deal with what tourists cared most about when traveling. From a policy research standpoint, this can ensure such findings from best practices. As shown in Table 2, interviews were conducted with 20 practitioners from September to October in 2017, comprising tourists, tourism experts, tourism enterprise managers, and tourism administrators, to explore their different views on TMR to ensure triangulation. The respondents were selected via snowball sampling. The research demonstrates flexibility with interviews and focus groups so as to obtain in-depth data. The researchers collected and continuously analyzed data until no new dimensions were generated, which indicated information saturation (Small 2009).

The interviews mainly focused on three open questions. The first question asked about the concept of TMR, including its dimensions and characteristics. The second question concerned the items the interviewees cared most about when traveling. Firstly, it's to identify problems affecting consumers in the tourism sector; secondly, to identify the regulatory response from the government through legislation; and third, to identify whether tourists were aware of the legislation and what impact it had had on their tourist activities. For instance, have they experienced any illegal activity or unethical practice? If so, how can 
the industry legislate and regulate against such activities or practices? The third question inquired about the interviewees' opinions on the current situation of TMR at the destination, including their views on current problems, the internal and external causes, and regulatory response. Qualitative research data were analyzed following the approaches proposed by Holsti (1968) and Strauss (1987).

\section{Table 2 here}

According to the scale development procedures proposed by Churchill (1979) and Rossiter (2002), TMR is defined by eliciting attributes from tourists and stakeholders. To ascertain the opinions of tourists and other stakeholders about TMR, the interview data, categories, properties, and dimensions were analyzed. The main point mentioned by the interviewees is that TMR in most countries serves to protect consumers. For instance, consumers should have the right to recover compensation for breach of contract. The following comments are enlightening:

People complain of being cheated by tour operators or other service providers. If there was proper regulation of the market, then you wouldn't have things like lawsuits or complaints over a situation. If tourists are abused by the tour operator or tour guides, there will be a mechanism to get redress against companies. (E01Male, University, China)

If we want to encourage the tourism industry, we've got to protect our customers, the tourists. (A04-Male, TB, China)

Another point extracted from the interviews is that TMR shows whether or not various market stakeholders comply with market rules. TMR requires legislations against illegal 
activity and self-regulation against unethical practice. Relevant comments include the following:

You see, that's hugely unethical behavior, but apparently it's not illegal. For instance, the tour guide turned around and said, I didn't force them, I just told them there's a place for the best souvenir market or supermarket. If you think of the zero commission, it's also not illegal but really unethical. It is essential to overcome these civilian practices. (E04-Male, University, UK)

TMR referred to a 'customer protection' and is as relevant to travel agencies as to hotels, transport, theme parks, and other attractions, covering all constituent parts of the tourism sector. TMR aimed to impose obligations on all the tourism suppliers to provide what they promise to do. (E04-Male, University, UK)

On the basis of qualitative analysis of the secondary and primary data, we define TMR as follows: "Tourism market regulation is an evolving process and a state in which market rules are complied with and adjusted by various market stakeholders in the context of an institutional environment designed to protect tourists. " From the perspective of tourists, the state of TMR depends on whether stakeholders can provide compliant tourism information in the pre-travel period, sign a compliant contract, fulfill tourism contracts during the travel period, and deal with tourists' feedback in the post-travel period according to the law and market rules. From tourists' perspective, TMR involves processive steps obtained from the tourists' whole experience. Tourists' travel experience depends on the services provided by various market stakeholders. 


\section{TMR Dimensions from Tourists' Perspective}

According to the open coding, axial coding, and selective coding suggested by Strauss (1987), TMR comprises five dimensions: regulatory oversight, truth in advertising, tourism contract compliance, fulfilling tourism contracts, and travel feedback processing.

Regulatory oversight is the basis for the formation of the TMR. Formal institutions, informal institutions, and implementation mechanisms constitute the institutional environment (Coase 2012; Helmke and Levitsky 2004; North 1990). Schultz (1968) defined an institution as a set of behavioral rules that define people's behavior patterns and restrict their mutual relations. From the perspective of tourists, regulatory oversight includes whether market transactions are fair and whether regulatory authorities can ensure the tourism market is regulated and tourists' interests are protected (Yao and Liu 2019). The government's role is to create an enabling environment by passing legislation, including that pertaining to tourism. The government and organizations should pass regulations promoting the development of the tourism industry, including rebuilding regulations, access regulations, and regulations governing tourist services. Relevant comments about this dimension include the following:

Institutions are very important because you need to know, as a tourist, that if you buy a product from one of these companies, it is guaranteed by the government or an association. It should really be a situation where the tourists' interests are protected. Governments can legislate for that. (G01-Male, MCA, China)

In the UK, there are organizations such as Air Transport Operation License and Association of British Travel Agents that take away licenses from members or suspend membership regulations, which means tourists are unlikely to buy a tour 
from that operator because there's no protection. (E04-Male, University, UK)

Truth in advertising is an important dimension for tourists to evaluate TMR. Travels can be risky because of the intangibility of tourism products and the unfamiliarity of tourists with a new destination (Gitelson and Crompton 1983). Thus, tourists want to receive extensive compliance information (Coromina and Camprubí 2016). They usually buy products based on the information supplied by the tourism enterprises or the DMOs. Therefore, it is important to provide true tourism information and marketing publicity that do not violate laws and regulations (Yao and Hou 2017). From the interviewees' perspective, the factors that disrupt TMR are false advertising and misleading information. As tourism transactions precede the purchased experience, previously publicized information is an important dimension for tourists to choose a travel product and judge whether the tourism market is regulated. One interviewee provided the following useful example:

Let's assume you go to London for two weeks. You book this hotel because it claimed to have a Chinese restaurant, to be located just five minutes' walk from the underground, and to provide a shuttle from the hotel to the airport. These three things persuade you to book this hotel. When you get there, these things don't exist, and that is not information compliance. So, Truth in advertising simply means the information that you provide to tourists is true. In the UK, we have something called the Advertising Standards Authority. You have to be very careful with the publicity brochure. (E04-Male, University, UK)

Tourism contract compliance is another important dimension for evaluating TMR. As one informant mentioned: "The tourism contract is what we call a meeting of two minds. 
One thing that determines what this means is what you promised me, and if I accept, then we agree in the contract. If you buy a tour, then that is your contract with the tour operator or whoever is selling it. The tour operator is responsible for the delivery of the tour" (C03Male, CA, China). Especially when booking through a travel agency, the signed travel contract should clearly state the contained product and what must be self-financed. As one respondent shared: "Although tourists do not always sign a formal contract when purchasing a tourism product, such as when reserving a hotel room or visiting a tourism attraction, the document provided by the hotel and signed by the tourist on arrival, which specifies the accommodation level, room specifications, check-in time, departure time, etc., is also a kind of contract. Another kind of contract is the tourist tickets purchased from a tourism attraction" (CO1-Male, LCD of TA, China).

Fulfilling tourism contracts is important because various businesses in the tourism market provide profit-making services according to the signed contracts. As one expert argued, "If they offer you a holiday or a flight, they have to comply with what they say they're offering, as tourists are expecting what they've been promised will be delivered according to the tourism contract" (E04-Male, University, UK). Therefore, whether a tourism contract is fulfilled is primarily determined by the tourists' expectations, according to which they evaluate whether the tourism company performs its contractual obligations. This evaluation includes whether the tourism products provided are consistent with the signed contract, whether the travel services meet the service standards agreed on by both parties, and whether the tourism enterprise or service staff does not deceive the tourists and force them to consume.

Travel feedback processing refers to the tourism business entities and regulatory authorities that deal with tourists' problems. It is another important dimension of TMR, as 
conveyed by the following comments: "Feedback, of course, might be normal if you buy something. And if negative, people really know they've got a problem" (T06-M, PT, China). "To me, the channel of complaints provided should be unobstructed and convenient. If the relevant regulatory authorities or company can respond to my complaint within 24 hours, I am very satisfied. If they just handle it, I am satisfied already” (T05-F, Student, China). Thus, from the perspective of tourists, travel feedback processing concerns whether regulators quickly respond to complaints, whether regulatory authorities and tourism enterprises quickly resolve complaints according to the law, whether the tourism feedback channel is unobstructed, and whether complaint-handling procedures are regulated.

\section{Study 2: Item Generation}

Churchill (1979) identified several ways to generate the initial items: literature search, experience surveys, focus groups, critical incident techniques, and insight-stimulating examples. In the present study, items were generated from the literature review and qualitative research (Churchill 1979; Hinkin et al. 1997). An extensive literature review was conducted to identify items relevant to TMR. This method yielded 11 items that were subsequently adopted as items of our TMR measurement scale. (Table 3 presents the items after subsequent revisions to improve content and face validity.) Through content analysis of the interview data and detailed documents of the laws, policies and enforcement capabilities, together with TMR dimensions from tourists' perspective in the Conceptualization step, additional 24 items were obtained across five dimensions. The literature review and qualitative approach generated 35 items in total.

\section{Study 3: Item Purification and Content Validity}

Content validity refers to the appropriateness for and consistency of the items with the 
measurement dimensions (Hair et al. 2010). After developing the initial items, the authors reviewed the wording and content validity to remove measurement items that did not satisfy the concept. As employed in previous scale-development research (Busser and Shulga 2018; Fetscherin and Stephano 2016; Kim, Homun, Walker, and Drane 2015), the most basic validity types are face and content validity (Chu and Murrmann 2006; Zikmund 1997). Ten experts were invited to examine the items with the aim of improving the content validity, specificity, clarity, conciseness, and readability of the scale (Busser and Shulga 2018; DeVellis 2003; Netemeyer, Bearden, and Sharma 2003). The experts comprised six university teachers specializing in tourism markets and four Ph.D. candidates. Following West and Crompton (2013), the experts were asked to complete content validity tasks to derive the final scale items. For each initial item, they were asked to judge the item's relevance to TMR and whether it can measure each dimension (using a five-point Likert scale from strongly disagree $=1$ to strongly agree $=5$ ). They were also asked to suggest additional items that would improve the scale's simplicity and content validity. Only items with an average score of 3 or higher were retained (Fetscherin and Stephano 2016; Sharma 2009). For example, the item "tourism services personnel not asking for tips" scored below 3. Although mainland China prohibits tour guides and tour leaders from asking for tips from tourists, under the Tourism Law (Standing Committee of the National People's Congress 2018), this item is not appropriate for other countries. Through several rounds of discussions with the experts, 27 of the initial items were retained.

Next, a focus group of six Ph.D. students specializing in tourism management was invited to revise the conciseness and readability of the items. The aim was to ensure that tourists would be able to clearly understand the meaning of each measurement item when completing the questionnaire. A pre-study scale was issued to a small sample to collect suggestions from tourists and modify the wording of the items accordingly before a large- 
scale investigation was conducted. In total, 61 questionnaires were distributed to tourists visiting the tourist attractions of Tianjin ancient cultural street, the Five Avenues, Tianjin Italian style street, Happy Valley, and water park as well as to tourists staying in hotels in Tianjin city in November 2017. The tourist respondents were mainly asked whether they could understand the items and if they had any suggestions to improve them. Several adjustments were made based on the feedback from the students and tourists to ensure that visitors would understand the meaning of each item. Finally, the validities of the 27 initial items were confirmed. Table 3 presents the 27 items in the finalized questionnaire.

\section{Table 3 here}

\section{Study 4: Scale Purification and Dimensionality}

\section{Sample Size and Analysis}

The first round of data collection yielded 415 valid questionnaires from the 500 distributed. The demographic profiles of the respondents are reported in Table 4. Females outnumbered males (54.5\% vs. $45.5 \%)$, and the largest age group was $18-25$ years old (35.2\%). Regarding education, $56.9 \%$ had an undergraduate degree, and as regards occupation, the largest group was students (32.8\%), followed by enterprise staff (22.4\%). The travel details report the destination the tourists last traveled to and the type of tourism enterprise that most recently provided them tourism products or services. Geographically, China's 34 provincial-level administrative areas are divided into seven major regions: Northeast China (3, representing the number of provincial-level administrative areas in the region), North China (5), East China (8), Central China (3), South China (5), Southwest China (5), and Northwest China (5). As Table 4 shows, $34.0 \%$ of the respondents last traveled to North China.

\section{Table 4 here}




\section{Exploratory Factor Analysis}

The items were generated through a qualitative approach and literature review. Hence, EFA was conducted to purify the items representing the conceptualized domain of the construct and identify the latent factor structure. Before EFA was performed, descriptive statistics, homogeneity analysis, Kaiser-Meyer-Olkin (KMO), and Bartlett's test of sphericity (BTS) were used to determine the appropriateness of the 415 valid first-round questionnaires. First, descriptive statistics were used to test the sufficiency of discrimination in the scale. The standard deviation was above 1 for all 27 items, indicating good discrimination (Appendix C). The univariate skewness and kurtosis values all ranged near -1 to +1 , indicating normality and thus appropriateness for factor analysis (Hair et al. 2010; Kline 2005). Second, homogeneity analysis was conducted using reliability statistics and item-total statistics. The Cronbach's alpha was 0.946 , higher than the recommended value of 0.7 (Nunnally 1994). Corrected item-total correlations all exceeded 0.40 (Thompson 2004), and the index "Cronbach's alpha if item deleted" did not increase (Field 2013). These findings all demonstrated the reliability and internal consistency of the scale. Third, the KMO index was 0.940, which exceeded the threshold of 0.50 (Kaiser 1974). Bartlett's index (approx. chi-square $=7252.495, \mathrm{df}=351, \mathrm{p}<0.000)$ was significant. These two findings indicated that the sample had sufficient correlations to conduct factor analysis.

The principal component analysis with eigenvalues greater than 1.0 (Kaiser's criterion) and maximum variable rotation was used in the EFA process to explore dimensionality. The aim was to specify the observed items and the assumed underlying factors. Five dimensions with eigenvalues above 1 were identified which explained $66.78 \%$ of the total variance. Items with a factor loading below 0.50 , high cross loading on another factor $(>0.5)$, and low commonalities $(<0.30)$ were eliminated (Hair et al. 2010). Furthermore, with the use of the index "Cronbach's alpha if item deleted," items were removed if deleting them raised the 
reliability coefficient of their dimension (Field 2013). As recommended by prior research (Kim et al. 2015; Kline 2005; Raubenheimer 2004), at least three items were retained for each dimension. The application of these criteria omitted 4 items. EFA was again conducted on the remaining 23 items. Table 5 presents the results. The KMO was 0.925 and the BTS $\left(\chi^{2}=5953.20, \mathrm{p}<0.000\right)$ was significant. Rotation converged in six iterations, and the 23 items were classified into five factors that explained $68.93 \%$ of the total variance.

Cronbach's alpha ranged from 0.781 to 0.902 and was above the cut-off value of 0.70 (Nunnally 1994). All the indicators showed that the explored dimensions had internal consistency reliability. On the basis of the literature review and the results of the inductive approach, the five dimensions were labeled as follows: regulatory oversight (RO, five items, $\alpha=.894$ ); fulfilling tourism contract (FTC, five items, $\alpha=.883$ ); travel feedback processing (TFP, five items, $\alpha=.902$ ); tourism contract compliance (TCC, four items, $\alpha=.781$ ); and truth in advertising (TIA, four items, $\alpha=.801$ ).

\section{Table 5 here}

\section{Study 5: Scale Validation}

\section{Sample Size and Analysis}

CFA was conducted to further validate the underlying structure and confirm the dimensionality of the scale. Factor analysis can be approached in two ways. One is to randomly split a data sample into two convenience sub-samples for EFA and CFA, as demonstrated in previous scale-development research (e.g., Busser and Shulga 2018; Chen, Bao, and Huang 2014; Wang, Hung, and Li 2018). The other, which Churchill (1979) recommended, is to explore dimensionality with the first round of data and then collect and analyze a new data sample with the purified questionnaire. As a means of assessing reliability and construct validity, this second approach has been widely used to develop 
improved measures (e.g., Chu and Murrmann 2006; Fetscherin and Stephano 2016; Liu, Wang, Huang, and Chen 2017; Wen et al. 2018). The current study followed Churchill's recommendation, which yielded 319 valid questionnaires from the 400 distributed (Appendix B). The item ratio was 13.9:1, higher than the standard 10:1 (Hair et al. 2010; Kline 2005; Nunnally 1994).

The demographic profiles and most-recent travel details of the respondents are shown in Table 4. Females slightly outnumbered males (52.66\% vs. $47.34 \%$, respectively). The largest age group was 26-30 years old (26.02\%), and the majority of participants had an undergraduate degree (55.80\%). Regarding occupation, the largest group was students (21.94\%), followed by enterprise staff $(20.38 \%)$. The destinations the tourists last traveled to were distributed among all 34 provincial-level administrative areas and abroad. The standard deviation was above 1 for all 23 items. The univariate skewness and kurtosis values ranged from -1 to +1 , except the item "the travel contract is signed with the consent of both parties" (Appendix D), which did not range outside -3 to +3 . The results confirmed the appropriateness of factor analysis (Hair et al. 2010; Kline 2005).

\section{Confirmatory Factor Analyses}

The 319 valid responses were analyzed with CFA using AMOS 24.0 to assess the model's reliability and validity. Specifically, the analysis aimed to establish whether TMR can be effectively measured through regulatory oversight, truth in advertising, tourism contract compliance, fulfilling tourism contracts, and travel feedback processing. The model was statistically evaluated by several goodness-of-fit statistics, including chi-squared to degrees of freedom ratio $\left(\chi^{2} / \mathrm{df}\right)$, comparison fit index $(\mathrm{CFI}>0.90)$, incremental fit index (IFI > 0.90), Tucker-Lewis index (TLI > 0.90), and root mean square error of approximation (RMSEA < 0.08) (Busser and Shulga 2018; Hair et al. 2010). The results were as follows: 
$\chi 2=592.932, \mathrm{df}=220, \chi 2 / \mathrm{df}=2.695, \mathrm{CFI}=0.908, \mathrm{IFI}=0.909, \mathrm{TLI}=0.894$, and

RMSEA $=0.073$. The modification indices and covariances reveal that 3 items were omitted because of high error and M.I. with other items: "travel services meet service standards agreed by both parties," "tourism complaints handling procedures are regulated," and "the travel contract is signed with the consent of both parties." The goodness-of-fit statistics were as follows: $\chi 2=352.750, \mathrm{df}=160 \chi 2 / \mathrm{df}=2.205, \mathrm{CFI}=0.943, \mathrm{IFI}=0.944, \mathrm{TLI}=0.932$, and RMSEA $=0.062$. These findings indicate that the five-factor structural model has better fitting degree than the model with 20 items.

Reliability refers to the degree of consistency of the results when the same object is repeatedly measured (Hair et al. 2010). Cronbach's alpha and CR were used to test the scale's internal consistency. CR concerns the internal consistency of a composite factor comprising more than one item (Fornell and Larcker 1981). Cronbach's alpha for each of the five dimensions ranged between 0.738 and 0.887 , while the CR of the five latent variables was between 0.748 and 0.898 (Table 6), therefore exceeding the cut-off value of 0.6 (Bagozzi and Yi 1988).

Convergent validity was evaluated by calculating the factor loadings of all the items $(\mathrm{FL}>0.5)$ (Hair et al. 2010) and the average variance extracted (AVE > 0.50) (Fornell and Larcker 1981). Table 6 shows that all items had significant loadings between 0.587 and 0.919, thus exceeding the criterion of 0.5 . The AVE of the five dimensions ranged between 0.496 and 0.692 , higher than the 0.45 threshold of a newly development scale recommended by Netemeyer, Bearden, and Sharma (2003). Overall, the scale is considered to have good convergent validity between the constructs.

\section{Table 6 here}

Discriminant validity refers to the low correlation or significant difference between the potential dimension and the other dimensions (Hair et al. 2010). If the square root of the 
AVE value is higher than the correlation coefficient among the constructs, then good discriminant validity is indicated (Fornell and Larcker 1981). Kline (2005) also recommended that the correlation coefficient between constructs should not exceed 0.85 . As shown in Table 7, the differences in the chi-squared values among the various dimensions all reach a significant level. The correlation coefficients of the five latent variables range from 0.214 to 0.670 , less than the square root of the AVE value of the five dimensions. The correlations between the constructs were all below 0.85 . Thus, all the indicators showed good discriminant validity. Furthermore, the normalized regression coefficients for the five factors were significant at $p<0.001$, indicating that the five factors can effectively measure TMR with nomological validity.

Table 7 here 


\section{Discussion and Implications}

Despite the rapid growth of China's tourism market and the increasing importance of TMR to protect tourists, great ambiguity still surrounds the conceptualization of TMR and how it should be measured. This study developed a set of standards to evaluate TMR to protect the rights of tourists and preserve the ethical integrity of the industry. The generated scale covers illegal practices and unethical behaviors, both of which impact the experience and overall satisfaction of tourists. This study developed a measurement scale to monitor these two parts.

The theoretical implications are summarized as follows. First, this study provides a theoretical framework for TMR, which is a multi-dimensional concept. Second, from the perspective of tourists, this study delineates the conceptual domain of TMR by identifying five dimensions. Regulatory oversight is the most important dimension because the institutional environment is the foundation for reflecting on whether the tourism market is regulated (Coase 2012; North 1990; Williamson 1996). The following dimension tourists care the most about is fulfilling tourism contracts, for if every company can comply with the contract to deliver products and services, then the tourism market will be well regulated. The other dimensions are travel feedback processing, tourism contract compliance, and truth in advertising. In the pre-travel period, truth in advertising is an important dimension because tourists always acquire and select information at different stages of their decision-making before starting a journey (Coromina and Camprubí 2016; Fodness and Murray 1999;

Gitelson and Crompton 1983). As Sirakaya and Woodside (2005) state, "a tourist is expected to be highly involved in the information search for tourism service purchases compared to many other product or service purchases, because of unfamiliarity and high-perceived risk." Therefore, tourism information should be transparent, true, and should not violate laws or regulations. The other dimensions are tourism contract compliance and fulfilling tourism contracts in the travel period and travel feedback processing in the post-travel period. From 
the perspective of tourists, these dimensions of TMR are sequential. Third, the present study is the first attempt to develop a measurement scale of TMR from the perspective of tourists. Tourists tend to have the best insight on the extent to which a tourism market is regulated, and they can evaluate TMR according to their travel experiences. Thus, this study provides a new research perspective and a reliable measurement tool for follow-up empirical research and enactment of legislation to address deficiencies in laws affecting tourism activity. It also provides theoretical foundations for the in-depth study of TMR in China and other destinations.

The conceptualization of TMR and the TMR measurement scale also have valuable practical implications. A disordered tourism market has become a serious obstacle to the healthy development of the tourism industry, especially in developing countries such as China. This problem necessitates research into the concept of TMR and its sub-components. The multi-dimensional TMR scale proposed herein is a useful tool for tourists, DMOs, and other stakeholders to measure and govern TMR. First, for tourists, the scale can provide information on TMR when they select and compare tourism products according to the standard of the items. The scale can be used to assess the perceived order of the tourism market before, during, and after traveling. For tour operators or other tourism enterprises, soliciting such information from tourists can help them identify what improvements are needed. They can use the scale in their training menu, such as employee training rules and employee performance appraisal, among other aspects. They can self-regulate and cultivate informal institutions to ensure product quality and further improve market competitiveness. For tourism administration and DMOs, soliciting such information from tourists can help them measure the status of TMR in destinations within their jurisdiction, enabling them to identify what regulations are needed to regulate the market. Second, the conceptualization identifies that the status of institutions and the compliance with the rules of market 
stakeholders are key criteria for determining the status of TMR. Therefore, these standards should be used to measure and govern TMR. Third, tourism administrations and DMOs can consider putting the items into laws and regulations. For example, regarding regulatory oversight, as the immaturity of the market environment is a main reason for the lack of regulation in China's tourism market (Du 2012), tourism administrations and DMOs should cooperate to perfect the formal institutions, informal institutions, and implementation mechanisms for creating a fair institutional environment. The government needs to upgrade the relevant laws and regulations in the tourism industry and provide more detailed clauses for improved implementation of the laws. 


\section{Conclusion and Limitations}

This study refined the domain of TMR and developed a measurement scale of TMR from the perspective of tourists by using a mixed-method and multi-step procedure. Qualitative research, including interviews and focus groups, was conducted to provide a clear definition of TMR and its sub-components. Face and content validity tests were performed to purify the items, thereby finalizing the 27 items for the questionnaire. Through the quantitative approach, EFA and CFA were used with two rounds of data, and 20 items across five dimensions were verified with satisfactory reliability and validity. The extracted dimensions of TMR from the perspective of tourists included regulatory oversight, truth in advertising, tourism contract compliance, fulfilling tourism contract, and travel feedback processing.

Although this research provides timely theoretical contributions for TMR and practical implications for the tourism market, it has several limitations. First, even with all the data collected in China, cross-cultural reliability and validity (Knight 1997) were not tested in this study (Liu et al. 2017). To further validate the scale, future research could replicate the current study using data from other cultural contexts. With a specific focus on China, it is our intention in follow-up research to examine and compare the Chinese position with selected tourist-receiving countries and identify gaps in tourism consumer protection regulations and recommend where further action may be needed to improve coverage in China. Second, this study only explores measurements of TMR from the perspective of tourists. Future research can further develop the measurement scale by considering the perspectives of other stakeholders (e.g., tourism enterprises, DMOs, etc.), thereby enriching TMR research. Third, this study develops the items from the perspective of tourists by following Hayek's Sensory Order, according to which market regulation can be perceived by consumers. We acknowledge that some measurement items may be difficult for tourists to make an informed response, for example, "the laws and regulations protecting tourists are perfect" and "the 
institutions regulating the tourism market are sound". Future research can be considered to further refine the survey instruments. Additionally, the influence of TMR on tourists' behavior and psychological outcomes, including first-time travel intention, willingness to travel again, and destination loyalty, can be investigated. Another study could examine on a compare and contrast basis China's existing tourism market regulations with other countries to discern discrepancies in coverage and recommend further improvements. 


\section{References}

Association of British Travel Agents. 2018. "Who we are." https://www.abta.com/ (accessed September 1, 2017).

Bagozzi, R. P., and Y. Yi. 1988. “On the Evaluation of Structural Equation Models.” Journal of the Academy of Marketing Science 16 (1): 74-94.

Baldwin, R., M. Cave, and M. Lodge. 2011. Understanding Regulation: Theory, Strategy, and Practice. New York, NY: Oxford University Press.

Breitsohl, J., and B. Garrod. 2016. “Assessing Tourists' Cognitive, Emotional and Behavioural Reactions to an Unethical Destination Incident.” Tourism Management 54: 209-220.

Busser, J. A., and L. V. Shulga. 2018. "Co-created Value: Multidimensional Scale and Nomological Network." Tourism Management 65: 69-86.

Cavicchi, A., and C. Santini. 2011. "Brunellopoli: A Wine Scandal under the Tuscan Sun." Tourism Review International 15 (3): 253-267.

Chen, G., J. Bao, and S. Huang. 2014. 'Developing a Scale to Measure Backpackers' Personal Development.” Journal of Travel Research 53 (4): 522-536.

China National Tourism Administration. 2017. The Yearbook of China Tourism Statistics 2016. Beijing: China Travel and Tourism Press.

China National Tourism Administration. 2016. The Yearbook of China Tourism Statistic 2015. Beijing: China Travel and Tourism Press.

Chu, K. H., and S. K. Murrmann. 2006. "Development and Validation of the Hospitality Emotional Labor Scale.” Tourism Management 27 (6): 1181-1191.

Churchill, G. A. 1979. “A Paradigm for Developing Better Measures of Marketing Constructs.” Journal of Marketing Research 16 (1): 64-73.

Coase, R. H. 2012. The Firm, the Market and the Law, University of Chicago Press. First 
published in 1937.

Commons, J. R. 1931. "Institutional Economics.” The American Economic Review 21 (4): 648-657.

Coromina, L., and R. Camprubí. 2016. "Analysis of Tourism Information Sources Using a Mokken Scale Perspective.” Tourism Management 56: 75-84.

Crotts, J. C., B. Pan, and A. E. Raschid. 2008. “A Survey Method for Identifying Key Drivers of Guest Delight.” International Journal of Contemporary Hospitality Management 20 (4): 462-470.

DeVellis, R. F. 2012. Scale Development: Theory and Applications (3rd ed.). Thousand Oaks, CA: Sage Publications.

Drahos, P. 2017. Regulatory Theory: Foundations and Applications. ANU Press.

Du, J. 2012. "The Main Problems, Causes and Countermeasures of Current Tourism Market." Reference Theory (9): 14-17.

Field, A. 2013. Discovering Statistics Using IBM SPSS Statistics (4th ed.). London: SAGE.

Fetscherin, M., and R. M. Stephano. 2016. “The Medical Tourism Index: Scale Development and Validation.” Tourism Management 52: 539-556.

Fodness, D., and B. Murray. 1999. "A Model of Tourist Information Search Behavior." Journal of Travel Research 37 (3): 220-230.

Fornell, C., and D. Larcker. 1981. "Evaluating Structural Equation Models with Unobservable Variables and Measurement Errors.” Journal of Marketing Research 18 (1): 39-50.

Frechtling, D C. 1999. “The Tourism Satellite Account: Foundations, Progress and Issues.” Tourism Management 20: 163-170.

Frechtling, D C. 2010. “The Tourism Satellite Account: A Primer.” Annals of Tourism Research 37(1): 136-153. 
Fu, L. 2010. "On the Legal Solution for the Problem of 'Free-of-charge or Negative-charge tours' Practice.” Tourism Tribune 25 (9): 71-76.

Gefen, D., E. Karahanna, and D. W. Straub. 2003. "Trust and TAM in Online Shopping: An Integrated Model.” MIS Quarterly 27 (1): 51-90.

Ghosh, T., and S. Mandal. 2018. "Medical Tourism Experience: Conceptualization, Scale Development, and Validation.” Journal of Travel Research 1-14.

Gitelson, R. J., and J. L. Crompton. 1983. "The Planning Horizons and Sources of Information Used by Pleasure Vacationers." Journal of Travel Research 21 (3): 2-7.

Grant, D. 1996. "The Package Travel Regulations 1992." Tourism Management 17 (5): 319_ 321.

Hall, C.M. 2012. Medical Tourism: The Ethics, Regulation, and Marketing of Health Mobility, Routledge, London.

Hair, J. F., W.C. Black, B. J. Babin, and R. E. Anderson. 2010. Multivariate Data Analysis (7th ed.). Upper Saddle River, NJ: Pearson Education.

Harris, L. C. 2012. “'Ripping Off' Tourists: An Empirical Evaluation of Tourists' Perceptions and Service Worker (Mis)Behavior.” Annals of Tourism Research 39 (2): 1070-1093.

Hayek, F. A. 1952. The Sensory Order: An Inquiry into the Foundations of Theoretical Psychology. Chicago: University of Chicago Press.

Hayek, F. A. 1967. Studies in Philosophy, Politics and Economics. Chicago: The University of Chicago Press.

Helmke, G., and S. Levitsky. 2004. "Informal Institutions and Comparative Politics: A Research Agenda." Perspectives on Politics 2 (4): 725-740.

Hinkin, T., B. Tracey, and C. Enz. 1997. "Scale Construction: Developing and Reliable and Valid Measurement Instruments.” Journal of Hospitality and Tourism Research 21 (1): $100-120$. 
Holsti, O. 1968. Content Analysis in Lindzey, G. and Aaronson (Eds.) The Handbook of Social Psychology. Reading, MA: Addison-Wesley Publishing.

Hong, Y. 2005. "Market Order Construction in the Economic Transformation Stage." Economic Theory and Economic Management (1): 5-11.

Hung, K., and J. F. Petrick. 2010. "Developing a Measurement Scale for Constraints to Cruising.” Annals of Tourism Research 37(1): 206-228.

Huybers, T., and J. Bennett. 1997. "The Significance of the Environment and its Regulation to Australia's Tourism Industry.” Australasian Journal of Environmental Management 4 (1): 40-55.

Jenkins, C. L. 2012. “Tourism and Political Change.” Tourism Management 33 (3): 721-722. Jia, Y., J. He, and F. Cui. 2006. “An Analysis of Interactions Between Zero Inclusive-fee and China's Outbound Tourism.” Tourism Tribune 21 (1): 69-73.

Kaiser, H. F. 1974. “An Index of Factorial Simplicity.” Psychometrika 39 (1): 31-36.

Kline, R. B. 2005. Principles and Practice of Structural Equation Modeling (2nd ed.). New York, NY: Guilford.

Kim, J., and B. Gerber. 2005. "Bureaucratic Leverage over Policy Choice: Explaining the Dynamics of State-level Reforms in Telecommunications Regulation.” The Policy Studies Journal 33 (4): 613-33.

Kim, W., H. M. Jun, M. Walker, and D. Drane. 2015. "Evaluating the Perceived Social Impacts of Hosting Large-scale Sport Tourism Events: Scale Development and Validation.” Tourism Management 48: 21-32.

King, B., L. Dwyer, and B. Prideaux. 2006. “An Evaluation of Unethical Business Practices in Australia's China Inbound Tourism Market.” International Journal of Tourism Research, 8 (2): 127-142. 
Knight, G. A. 1997. “Cross-cultural Reliability and Validity of a Scale to Measure Firm Entrepreneurial Orientation.” Journal of Business Venturing 12 (3): 213-225.

Kohl, J. P., and P. S. Greenlaw. 1983. "Government Regulation and Hospitality Management.” International Journal of Hospitality Management 2 (1): 25-29. Legislative Council of Hong Kong SAR. 2018. "Travel Industry Ordinance (No.37 of 2018)." https://www.gld.gov.hk/egazette/pdf/20182249/es12018224937.pdf (accessed December 21, 2018).

Li, J., L. Xie, and X. Guan. 2016. "Scale Development and Validation of Tourism Public Service Quality.” Tourism Tribune 31 (11): 117-127.

Ling, C. 2014. "A Study on Reasons and Solutions to Tour Guides' Ripping Off Tourist.” American Journal of Industrial and Business Management 4 (2): 90-93.

Liu, C. R., Y. C. Wang, W. S. Huang, and S. P. Chen. 2017. "Destination Fascination: Conceptualization and Scale Development.” Tourism Management 63: 255-267. Lv, X., H. Xu, and W. Qiu. 2014. "Construction and Validity Test of China Tourism Consumer Power Scale.” Economic Management (7): 111-119.

Mak, A. H. N., K. K. F. Wong, and R. C. Y. Chang. 2011. "Critical Issues Affecting the Service Quality and Professionalism of the Tour Guides in Hong Kong and Macau.” Tourism Management 32 (6): 1442-1452.

Marx, K. 1867. Capital. First published in German in 1867, English edition first published in 1887, translated by Samuel Moore and Edward, Aveling-edited by Fredrick Engels, Moscow, USSR: Progress Publishers.

March, R. 2008. "Towards a Conceptualization of Unethical Marketing Practices in Tourism: A Case-study of Australia's Inbound Chinese Travel Market.” Journal of Travel and Tourism Marketing 24 (4): 285-296. 
Mcknight, D. H., and N. L. Chervany. 2001. "What Trust Means in E-commerce Customer Relationships: An Interdisciplinary Conceptual Typology.” International Journal of Electronic Commerce 6 (2): 35-59.

Ministry of Culture and Tourism of the people's Republic of China. 2019. "Basic situation of Tourism Market in 2018.”

http://zwgk.mct.gov.cn/auto255/201902/t20190212_837271.html?keywords $=($ accessed February 12, 2019).

Netemeyer, R. G., W. O. Bearden, and S. Sharma. 2003. Scaling Procedures: Issues and Applications. London, UK: Sage.

North, D. C. 1990. Institutions, Institutional Change and Economic Performance. London: Cambridge University Press.

Nunnally, J. C. 1994. Psychometric Theory (3rd ed.). New York, NY: McGraw-Hill. Powell, W. W. 1990. "Neither Market nor Hierarchy: Network Forms of Organization.” Research in Organizational Behavior 12: 295-336.

Qu, R., C. Ennew, and M. T. Sinclair. 2005. “The Impact of Regulation and Ownership Structure on Market Orientation in the Tourism Industry in China.” Tourism Management 26 (6): 939-950.

Randle, E. J., and R. Hoye. 2016. "Stakeholder Perception of Regulating Commercial Tourism in Victorian National Parks, Australia.” Tourism Management 54: 138-149. Ren, L., and H. Qiu. 2018. "Developing a Measurement Scale for Cultural Values and Norms of Chinese Mass Travelers.” Journal of Hospitality and Tourism Management 1-8. Research Group on the Evaluation of Market regulation. 1998. “Assessment System of Market Order in Modern China.” Teaching and Research (1): 21-24.

Riefler, P., A. Diamantopoulos, and J. Siguaw. 2012. “Cosmopolitan Consumers as a Target Group for Segmentation.” Journal of International Business Studies 43 (3): 285-305. 
Rossiter, J. R. 2002. "The C-OAR-SE procedure for scale development in marketing." International Journal of Research in Marketing, 19(4): 305-335.

March, R. 2008. “Towards a Conceptualization of Unethical Marketing Practices in Tourism: A Case-study of Australia's Inbound Chinese Travel Market." Journal of Travel and Tourism Marketing 24 (4): 285-296.

Schultz, T. W. 1968. "Institutions and the Rising Economic Value of Man.” American Journal of Agricultural Economics 50 (5): 1113-1122.

Sharma, P. 2009. "Measuring Personal Cultural Orientations: Scale Development and Validation.” Journal of the Academy of Marketing Science 38 (6): 787-806.

Small, M. L. 2009. “'How Many Cases do I Need?' On Science and the Logic of Case Selection in Field-based Research.” Ethnography 10 (1): 5-38.

Smeral, E. 2006. "Tourism Satellite Accounts: A Critical Assessment.” Journal of Travel Research 45 (1): 92-98.

Smith, A. 1776. An Inquiry into the Nature and Causes of the Wealth of Nations. First published in 1776, edited by Adam Smith in 1778, 1784, 1786, 1789.

Sirakaya, E., and A. G. Woodside. 2005. "Building and Testing Theories of Decision Making by Travellers.” Tourism Management 26 (6): 815-832.

Standing Committee of the National People's Congress. 1997. "Price Law." http://www.npc.gov.cn/wxzl/gongbao/1997-12/29/content_1480187.htm (accessed June 10, 2017).

Standing Committee of the National People's Congress. 1999. "Contract Law." http://www.npc.gov.cn/npc/flsyywd/minshang/node_2196.htm (accessed June 10, 2017). 
Standing Committee of the National People's Congress. 2013. "Consumer Protection Law." http://www.npc.gov.cn/npc/xinwen/2013-10/26/content_1811773.htm (accessed June 10, 2017).

Standing Committee of the National People's Congress. 2018. "Advertising Law." http://www.npc.gov.cn/npc/xinwen/2018-11/05/content_2065663.htm (accessed November 5, 2018).

Standing Committee of the National People's Congress. 2018. "Tourism Law." http://www.npc.gov.cn/npc/xinwen/2018-11/05/content_2065666.htm (accessed November 5, 2018).

Standing Committee of the National People's Congress. 2019. "Law Against Unfair Competition." http://www.npc.gov.cn/npc/xinwen/2019-05/07/content_2086834.htm (accessed May 7, 2019).

Strauss, A. 1987. Qualitative Analysis for Social Scientists. Cambridge: Cambridge University Press.

Tang, J. 2013. "The Limitation and Perfection of the Tourism Service Contract Provisions in the Tourism Law.” Tourism Tribune 28 (9): 22-23.

The European Parliament and the Council of European Union. 2015. "Directive (EU) 2015/2302 of the European Parliament and of the Council." Official Journal of the European Union 1-33.

The People's Daily. 2019. "Tourism Complaints in 2018." http://travel.people.com.cn/n1/2019/0222/c41570-30897023.html (accessed February 22, 2019).

Thomas, R., and H. Thomas. 1992. "State Regulation and the Hospitality Industry: The Case of Hot Food Take-aways." International Journal of Hospitality Management 11 (3): $197-211$. 
Thompson, B. 2004. Exploratory and Confirmatory Factor Analysis: Understanding Concepts and Applications. Washington, DC: American Psychological Association.

Viktorovna, R. M., E. S. Vasilievna, T. E. Shamilevna, and L. E. Yurievna. 2014.

"Institutionalization of Tourist Rights Protection as an Indispensable Condition of the Tourism Development Strategy.” World Applied Sciences Journal 193-195.

Wang, G. 1997. Market Order Theory. Shanghai University of Finance and Economics Press. Wang, S., K. Hung, and M. Li. (2018). “Development of Measurement Scale for Functional Congruity in Guest Houses." Tourism Management 68: 23-31.

Wei, M., and J. Yang. 2011. "Irrational Tourism Consumption of Zero Inclusive-fee and Negative Inclusive-fee: Reflection and Measurements.” Energy Procedia 5: 1416-1424. West, S. T., J. L. Crompton. 2013. "Who Ought to Receive What? An Instrument to Assess a Community’s Preferred Strategy for Allocating Leisure Service Resources.” World Leisure Journal 55 (1): 38-57.

Williamson, O. E. 1996. Markets and Hierarchies: Analysis and Antitrust Implications. Social Science Electronic Publishing 86 (343): 619.

Wilson, E., N. Nielsen, and J. Buultjens. 2009. "From Lessees to Partners: Exploring Tourism Publice Private Partnerships within the New South Wales National Parks and Wildlife Service.” Journal of Sustainable Tourism 17 (2): 269-285.

Yao, Y., P. Hou. 2018. “Study on Tourism Enterprise Integrity Evaluation System: A Tourists' Perspective.” Tourism Tribune 32 (12): 80-88.

Yao, Y., Y. Liu. 2019. “The Concept of Tourism Market Order and its Operational Mechanism: An Exploratory Research Based on Grounded Theory.” Tourism Tribune $1-15$.

Yen, C. H., S. H. Tsaur, and C. H. Tsai. 2018. “Tour Leaders' Job Crafting: Scale Development.” Tourism Management 69: 52-61. 
Zhang, H. Q., D. X. F. Fan, T. S. M. Tse, and B. King. 2016. “Creating a Scale for Assessing Socially Sustainable Tourism.” Journal of Sustainable Tourism 1-18.

Zhang, H. Q., V. C. S. Heung, and Y. Q. Yan. 2009. "Play or not to Play-An Analysis of the Mechanism of the Zero-commission Chinese Outbound Tours Through a Game Theory Approach.” Tourism Management 30 (3): 366-371.

Zhang, H. Q., Y. Q. Yan, and Y. Li. 2009. "Understanding the Mechanism Behind the ZeroCommission Chinese Outbound Package Tours.” International Journal of Contemporary Hospitality Management 21 (6): 734-751.

Zikmund, W. G. 1997. Business Research Methods. Fort Worth, TX: Dryden Press. 
Table 1. Procedure for Developing the Measurement Instrument

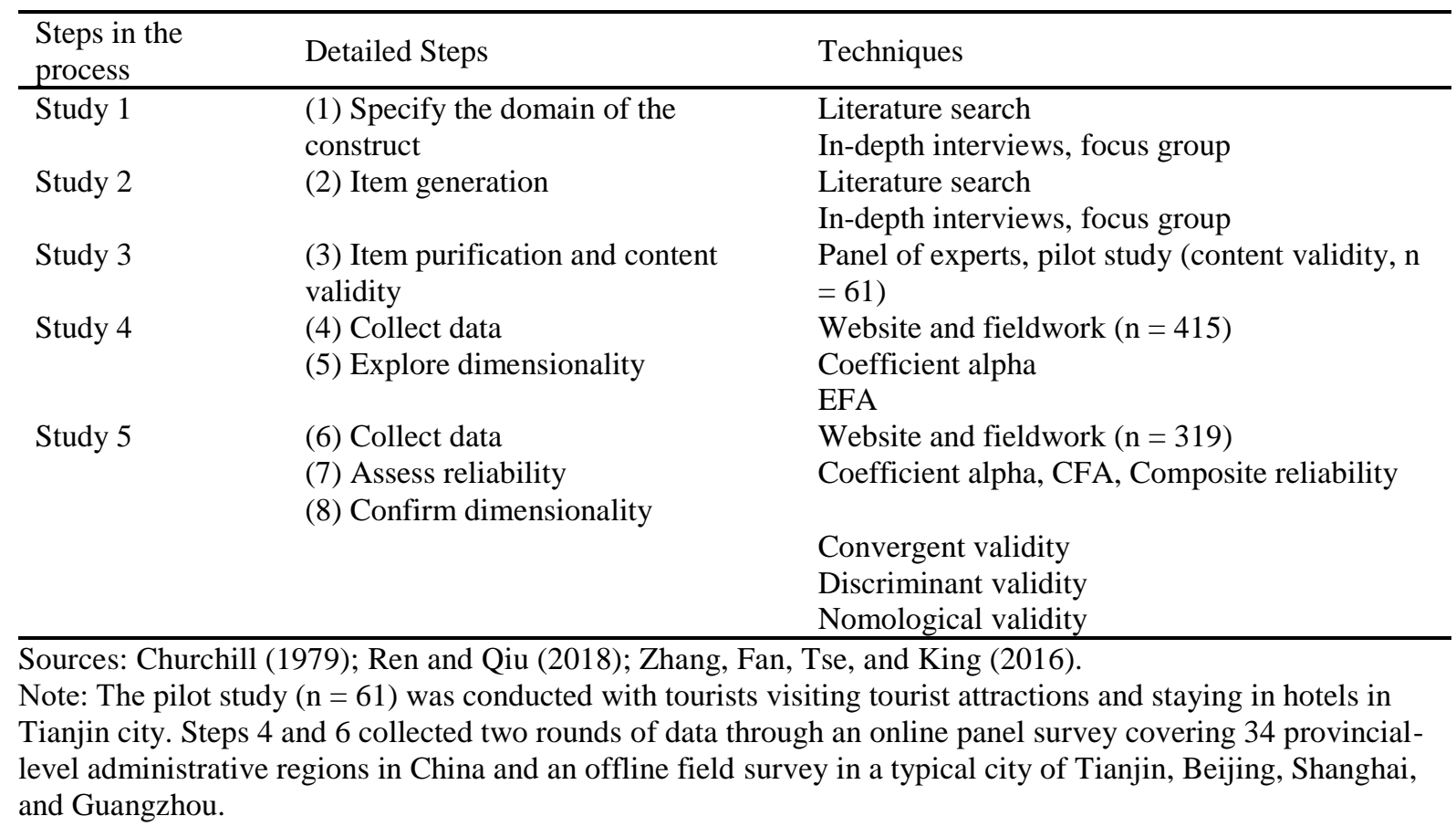

Table 2. Interviewee Profiles

\begin{tabular}{|c|c|c|c|c|c|c|c|c|}
\hline $\begin{array}{l}\text { Code } \\
\text { name }\end{array}$ & Type & Gender & $\overline{\text { Age }}$ & Education & Occupation & $\begin{array}{l}\text { Geographical } \\
\text { location }\end{array}$ & $\begin{array}{l}\text { Duration } \\
\text { (min) }\end{array}$ & Interview type \\
\hline T01 & \multirow[t]{6}{*}{ Tourist } & Male & 34 & Ph.D. & College teacher & Shandong & 100 & Focus group 1 \\
\hline T02 & & Male & 30 & Ph.D. & Ph.D. student & $\begin{array}{l}\text { Henan } \\
\text { province }\end{array}$ & 100 & Focus group 1 \\
\hline T03 & & Male & 28 & Ph.D. & Ph.D. student & $\begin{array}{l}\text { Neimenggu } \\
\text { province }\end{array}$ & 100 & Focus group 1 \\
\hline T04 & & Female & 31 & Ph.D. & College teacher & $\begin{array}{l}\text { Henan } \\
\text { province }\end{array}$ & 100 & Focus group 1 \\
\hline T05 & & Female & 25 & Ph.D. & Ph.D. student & $\begin{array}{l}\text { Jiangxi } \\
\text { province }\end{array}$ & 100 & Focus group 1 \\
\hline T06 & & Female & 36 & Bachelor & $\begin{array}{l}\text { Professional } \\
\text { traveler }\end{array}$ & $\begin{array}{l}\text { Sichuan } \\
\text { province }\end{array}$ & 42 & Interview \\
\hline E01 & \multirow{4}{*}{$\begin{array}{l}\text { Tourism } \\
\text { expert }\end{array}$} & Male & 53 & Ph.D. & Professor & Tianjin city & 28 & Interview \\
\hline E02 & & Female & 56 & Ph.D. & Professor & Tianjin city & 74 & Interview \\
\hline E03 & & Male & 31 & Ph.D. & Lecturer & $\begin{array}{l}\text { Guizhou } \\
\text { province }\end{array}$ & 55 & Interview \\
\hline E04 & & Male & 76 & Ph.D. & Professor & Glasgow, UK & 88 & Interview \\
\hline $\mathrm{C} 01$ & \multirow[t]{3}{*}{$\begin{array}{l}\text { Tourism } \\
\text { enterprise }\end{array}$} & Male & 39 & Master & $\begin{array}{l}\text { Manager of LCD } \\
\text { in TA }\end{array}$ & Beijing city & 67 & Interview \\
\hline $\mathrm{C} 02$ & & Female & 45 & Bachelor & $\begin{array}{l}\text { Tourism } \\
\text { entrepreneur }\end{array}$ & $\begin{array}{l}\text { Guangdong } \\
\text { province }\end{array}$ & 75 & Interview \\
\hline $\mathrm{C} 03$ & & Male & 60 & Bachelor & Manager of TA & Tianjin city & 112 & Interview \\
\hline A01 & \multirow{7}{*}{$\begin{array}{l}\text { Tourism } \\
\text { administration }\end{array}$} & Male & 55 & Master & Manager of MCT & Beijing city & 86 & Interview \\
\hline A02 & & Male & 53 & Bachelor & Manager of TB & Tianjin city & 118 & Focus group 2 \\
\hline A03 & & Male & 41 & Master & Manager of TB & Tianjin city & 118 & Focus group 2 \\
\hline A04 & & Male & 45 & Master & Manager of TB & $\begin{array}{l}\text { Jiangsu } \\
\text { province }\end{array}$ & 125 & Focus group 3 \\
\hline A05 & & Female & 30 & Bachelor & Staff of TB & $\begin{array}{l}\text { Jiangsu } \\
\text { province }\end{array}$ & 125 & Focus group 3 \\
\hline A06 & & Female & 37 & Bachelor & Manager of TB & $\begin{array}{l}\text { Jiangsu } \\
\text { province }\end{array}$ & 125 & Focus group 3 \\
\hline A07 & & Male & 41 & Bachelor & Manager of TB & $\begin{array}{l}\text { Jiangsu } \\
\text { province }\end{array}$ & 125 & Focus group 3 \\
\hline
\end{tabular}

Note: LCD: legal and compliance department; TA: travel agency; MCT: Ministry of Culture and Tourism; TB: Tourism Bureau. 
Table 3. Initial Constructs and Items Evaluating Tourism Market Regulation from the Perspective of Tourists

\begin{tabular}{|c|c|c|}
\hline Dimension & Items & Relevant literature \\
\hline \multirow{4}{*}{$\begin{array}{l}\text { Truth in } \\
\text { advertising }\end{array}$} & 1. Tourism information is transparent. & CAI \\
\hline & 2. Tourism information is true. & $\begin{array}{l}\text { CAI, Yao and Hou (2017), Article 32, } 48 \text { of Tourism } \\
\text { Law, Article } 20 \text { of Consumer Protection Law, } \\
\text { Article of Advertising Law }\end{array}$ \\
\hline & 3. There is no misleading tourism information. & $\begin{array}{l}\text { CAI, Article 32, } 97 \text { of Tourism Law, Article } 20 \text { of } \\
\text { Consumer Protection Law, Article 5, 9, 21, } 24 \text { of } \\
\text { Law Against Unfair Competition }\end{array}$ \\
\hline & $\begin{array}{l}\text { 4. Tourism information does not violate laws } \\
\text { and regulations. }\end{array}$ & Yao and Hou (2017) \\
\hline \multirow{6}{*}{$\begin{array}{l}\text { Tourism } \\
\text { contract } \\
\text { compliance }\end{array}$} & $\begin{array}{l}\text { 5. The travel contract is signed with the } \\
\text { consent of both parties. }\end{array}$ & CAI, Article 14 of Contract Law \\
\hline & 6. The travel contract clauses are specific. & CAI, Article 14 of Contract Law \\
\hline & $\begin{array}{l}\text { 7. The travel contract clearly states the } \\
\text { included product. }\end{array}$ & $\begin{array}{l}\text { CAI, Article } 58 \text { of Tourism Law, Article } 12 \text { of } \\
\text { Contract Law, Article } 26 \text { of Consumer Protection } \\
\text { Law }\end{array}$ \\
\hline & $\begin{array}{l}\text { 8. The travel contract clearly states the self- } \\
\text { financed items. }\end{array}$ & $\begin{array}{l}\text { CAI, Article } 12 \text { of Contract Law, Article } 26 \text { of } \\
\text { Consumer Protection Law }\end{array}$ \\
\hline & 9. Tourism products are clearly priced. & $\begin{array}{l}\text { CAI, Article } 12 \text { of Contract Law, Article } 26 \text { of } \\
\text { Consumer Protection Law, Article 13, } 42 \text { of Price } \\
\text { Law }\end{array}$ \\
\hline & $\begin{array}{l}\text { 10. There are no overruling clauses that } \\
\text { infringe on tourists' interests. }\end{array}$ & CAI, Article 39, 40, 41 of Contract Law \\
\hline \multirow[t]{6}{*}{$\begin{array}{l}\text { Fulfilling } \\
\text { tourism } \\
\text { contract }\end{array}$} & $\begin{array}{l}\text { 11. Tourism enterprises perform their } \\
\text { obligations according to the signed contract. }\end{array}$ & $\begin{array}{l}\text { CAI, Article 49,69, } 100 \text { of Tourism Law, Article } 8 \text {, } \\
60,107,108,113 \text { of Contract Law, Article } 16 \text { of } \\
\text { Consumer Protection Law }\end{array}$ \\
\hline & $\begin{array}{l}\text { 12. The tourism products provided are } \\
\text { consistent with the signed contract. }\end{array}$ & $\begin{array}{l}\text { CAI, Article } 9 \text { of Tourism Law, Article } 111,148 \text {, } \\
\text { 153, 154, } 155 \text { of Contract Law, Article 23, } 24 \text { of } \\
\text { Consumer Protection Law }\end{array}$ \\
\hline & $\begin{array}{l}\text { 13. Travel services meet service standards } \\
\text { agreed on by both parties. }\end{array}$ & $\begin{array}{l}\text { CAI, Article 9, } 58 \text { of Tourism Law, Article 111, 148, } \\
\text { 153, 154, } 155 \text { of Contract Law, Article } 8,10,23,24 \\
\text { of Consumer Protection Law }\end{array}$ \\
\hline & $\begin{array}{l}\text { 14. Tourism enterprises or service staff does } \\
\text { not arbitrarily suspend service activities. }\end{array}$ & $\begin{array}{l}\text { CAI, Article 41, 69, } 100 \text { of Tourism Law, Article } 8 \\
\text { of Contract Law }\end{array}$ \\
\hline & $\begin{array}{l}\text { 15. Tourism enterprises or service staff does } \\
\text { not force tourists to consume. }\end{array}$ & $\begin{array}{l}\text { CAI, Article 9, } 41 \text { of Tourism Law, Article 10, } 16 \text { of } \\
\text { Consumer Protection Law }\end{array}$ \\
\hline & $\begin{array}{l}\text { 16. Tourism enterprises or service staff does } \\
\text { not deceive tourists. }\end{array}$ & $\begin{array}{l}\text { CAI, Article } 35,41,98 \text { of Tourism Law, Article 52, } \\
54,113 \text { of Contract Law }\end{array}$ \\
\hline $\begin{array}{l}\text { Travel } \\
\text { feedback } \\
\text { processing }\end{array}$ & $\begin{array}{l}\text { 17. Tourism feedback channel is unobstructed. } \\
\text { 18. Tourism complaint-handling procedures }\end{array}$ & $\begin{array}{l}\text { CAI, Li (2016), Article } 91 \text { of Tourism Law } \\
\text { CAI, Li (2016); Drahos (2017) }\end{array}$ \\
\hline
\end{tabular}

processing are regulated.

19. Tourism enterprises give positive feedback on issues I raise.

20. Tourism enterprises quickly resolve my complaints according to the law.

21. Regulatory authorities deal with my complaints quickly.

22. Regulatory authorities quickly resolved my complaints according to the law.

Regulatory 23. The market transaction in tourism industry oversight is fair.

24. The laws and regulations protecting tourists are perfect.

25 . The institutions regulating the tourism market are sound.

26. Regulatory authorities ensure the tourism market is regulated.

27. Regulatory authorities protect tourists' interests.

CAI, Lv (2014)

CAI, Li (2016)

CAI, Li (2016), Article 88, 89 of Tourism Law, Article 35 of Consumer Protection Law CAI, Li (2016); Drahos (2017)

\section{CAI}

CAI

Gefen (2003)

CAI

McKnight (2002) 
Table 4. Demographic Profiles and Most Recent Travel Details of Respondents

\begin{tabular}{|c|c|c|c|}
\hline Variable & Category & $\begin{array}{l}\text { Distribution } \\
(\mathrm{N}=415)\end{array}$ & $\begin{array}{l}\text { Distribution } \\
(\mathrm{N}=319)\end{array}$ \\
\hline \multirow[t]{2}{*}{ Gender } & Male & $189(45.5 \%)$ & $151(47.34 \%)$ \\
\hline & Female & $226(54.5 \%)$ & $168(52.66 \%)$ \\
\hline \multirow[t]{6}{*}{ Age } & $18-25$ & $146(35.2 \%)$ & $62(19.44 \%)$ \\
\hline & $26-30$ & $72(17.3 \%)$ & $83(26.02 \%)$ \\
\hline & $31-40$ & $86(20.7 \%)$ & $72(22.57 \%)$ \\
\hline & $41-50$ & $62(14.9 \%)$ & $51(15.99 \%)$ \\
\hline & $51-60$ & $42(10.1 \%)$ & $33(10.34 \%)$ \\
\hline & 61 and above & $7(1.7 \%)$ & $18(5.64 \%)$ \\
\hline \multirow[t]{4}{*}{ Education } & Senior high school or below & $4(1.0 \%)$ & $15(4.70 \%)$ \\
\hline & Junior college & $53(12.8 \%)$ & $64(20.06 \%)$ \\
\hline & Undergraduate & $236(56.9 \%)$ & $178(55.80 \%)$ \\
\hline & Postgraduate or above & $122(29.4 \%)$ & $62(19.44 \%)$ \\
\hline \multirow[t]{8}{*}{ Occupation } & Government staff/civil servant & $24(5.8 \%)$ & $25(7.84 \%)$ \\
\hline & Enterprise staff & $93(22.4 \%)$ & $65(20.38 \%)$ \\
\hline & Teacher & $56(13.5 \%)$ & $46(14.42 \%)$ \\
\hline & Private business owner & $54(13.0 \%)$ & $43(13.48 \%)$ \\
\hline & Student & $136(32.8 \%)$ & $70(21.94 \%)$ \\
\hline & Freelancer & $15(3.6 \%)$ & $28(8.78 \%)$ \\
\hline & Retired & $12(2.9 \%)$ & $20(6.27 \%)$ \\
\hline & Other & $25(6.0 \%)$ & $22(6.90 \%)$ \\
\hline \multirow{8}{*}{$\begin{array}{l}\text { Travel } \\
\text { destination }\end{array}$} & Northeast China & $16(3.9 \%)$ & $12(3.76 \%)$ \\
\hline & North China & $141(34.0 \%)$ & $85(26.65 \%)$ \\
\hline & East China & $103(24.8 \%)$ & $67(21.00 \%)$ \\
\hline & Central China & $39(9.4 \%)$ & $37(11.60 \%)$ \\
\hline & South China & $25(6.0 \%)$ & $32(10.03 \%)$ \\
\hline & Southwest China & $38(9.2 \%)$ & $40(12.54 \%)$ \\
\hline & Northwest China & $22(5.3 \%)$ & $18(5.64 \%)$ \\
\hline & Abroad & $31(7.5 \%)$ & $28(8.78 \%)$ \\
\hline \multirow{5}{*}{$\begin{array}{l}\text { Types of } \\
\text { tourism } \\
\text { enterprises }\end{array}$} & Offline travel agency & $95(22.9 \%)$ & $60(18.81 \%)$ \\
\hline & Online travel enterprise & $98(23.6 \%)$ & $79(24.76 \%)$ \\
\hline & Tourism attraction & $211(50.8 \%)$ & $166(52.04 \%)$ \\
\hline & Hotel & $184(44.3 \%)$ & $137(42.95 \%)$ \\
\hline & Other & $49(11.8 \%)$ & $36(11.29 \%)$ \\
\hline
\end{tabular}


Table 5. Exploratory Factor Analysis Results for Tourism Market Regulation $(\mathrm{N}=415)$

\begin{tabular}{|c|c|c|c|c|c|c|}
\hline \multirow[t]{2}{*}{ NO. } & \multirow[t]{2}{*}{ Factors/Items } & \multicolumn{5}{|c|}{ Component } \\
\hline & & 1 & 2 & 3 & 4 & 5 \\
\hline & Regulatory oversight (RO) & & & & & \\
\hline Q25 & The institutions regulating the tourism market are sound. & 0.848 & & & & \\
\hline Q24 & The laws and regulations protecting tourists are perfect. & 0.835 & & & & \\
\hline Q27 & Regulatory authorities protect tourists' interests. & 0.748 & & & & \\
\hline Q23 & The market transaction in the tourism industry is fair. & 0.701 & & & & \\
\hline \multirow[t]{2}{*}{ Q26 } & $\begin{array}{l}\text { Regulatory authorities ensure the tourism market is } \\
\text { regulated. }\end{array}$ & 0.674 & & & & \\
\hline & Fulfilling tourism contracts (FTC) & & & & & \\
\hline Q16 & $\begin{array}{l}\text { Tourism enterprises or service staff does not deceive } \\
\text { tourists. }\end{array}$ & & 0.793 & & & \\
\hline Q15 & $\begin{array}{l}\text { Tourism enterprises or service staff does not force tourists } \\
\text { to consume. }\end{array}$ & & 0.787 & & & \\
\hline Q12 & $\begin{array}{l}\text { The tourism products provided are consistent with the } \\
\text { signed contract. }\end{array}$ & & 0.743 & & & \\
\hline Q14 & $\begin{array}{l}\text { Tourism enterprises or service staff does not arbitrarily } \\
\text { suspend service activities. }\end{array}$ & & 0.740 & & & \\
\hline \multirow[t]{2}{*}{ Q13 } & $\begin{array}{l}\text { Travel services meet service standards agreed on by both } \\
\text { parties. }\end{array}$ & & 0.584 & & & \\
\hline & Travel feedback processing (TFP) & & & & & \\
\hline Q21 & Regulatory authorities deal with complaints quickly. & & & 0.843 & & \\
\hline Q22 & $\begin{array}{l}\text { Regulatory authorities quickly resolve complaints } \\
\text { according to the law. }\end{array}$ & & & 0.829 & & \\
\hline Q17 & Tourism feedback channel is unobstructed. & & & 0.705 & & \\
\hline Q20 & $\begin{array}{l}\text { Tourism enterprises quickly resolve my complaints } \\
\text { according to the law. }\end{array}$ & & & 0.693 & & \\
\hline Q18 & $\begin{array}{l}\text { Tourism complaint-handling procedures are regulated. } \\
\text { Tourism contract compliance (TCC) }\end{array}$ & & & 0.661 & & \\
\hline Q7 & The travel contract clearly states the included product. & & & & 0.813 & \\
\hline Q8 & The travel contract clearly states the self-financed items. & & & & 0.715 & \\
\hline Q6 & Tourism products are clearly priced. & & & & 0.655 & \\
\hline \multirow[t]{2}{*}{ Q5 } & $\begin{array}{l}\text { The travel contract is signed with the consent of both } \\
\text { parties. }\end{array}$ & & & & 0.619 & \\
\hline & Truth in advertising (TIA) & & & & & \\
\hline Q1 & Tourism information is transparent. & & & & & 0.775 \\
\hline Q2 & Tourism information is true. & & & & & 0.746 \\
\hline Q4 & Tourism information does not violate laws and regulations. & & & & & 0.646 \\
\hline \multirow[t]{5}{*}{ Q3 } & There is no misleading tourism information. & & & & & 0.635 \\
\hline & Eigenvalue & 9.595 & 2.377 & 1.542 & 1.200 & 1.139 \\
\hline & Percentage of variance explained & 41.717 & 10.335 & 6.706 & 5.218 & 4.951 \\
\hline & Coefficient alpha & 0.894 & 0.883 & 0.902 & 0.781 & 0.801 \\
\hline & Number of attributes & 5 & 5 & 5 & 4 & 4 \\
\hline
\end{tabular}

Note: $\mathrm{KMO}=0.925$; Bartlett test of sphericity, $\chi 2=5953.20(\mathrm{p}<0.000)$. 
Table 6. Confirmatory Factor Analysis Results for the Final Model of Tourism Market Regulation $(\mathrm{N}=319)$

\begin{tabular}{|c|c|c|c|c|c|c|}
\hline Factors/Items & $\mathrm{CR}$ & AVE & $\begin{array}{l}\text { Factor } \\
\text { loading }\end{array}$ & SE & $\mathrm{CR}$ & $\begin{array}{l}\text { Cronbach's } \\
\text { alpha }\end{array}$ \\
\hline Truth in advertising (TIA) & 0.795 & 0.496 & & & & 0.790 \\
\hline Tourism information is transparent. & & & 0.649 & & & \\
\hline Tourism information is true. & & & 0.808 & 0.111 & 11.13 & \\
\hline There is no misleading tourism information. & & & 0.729 & 0.116 & 10.461 & \\
\hline $\begin{array}{l}\text { Tourist information does not violate laws and } \\
\text { regulations. }\end{array}$ & & & 0.614 & 0.104 & 9.156 & \\
\hline Tourism contract compliance (TCC) & 0.748 & 0.500 & & & & 0.738 \\
\hline $\begin{array}{l}\text { The travel contract clearly states the included } \\
\text { product. }\end{array}$ & & & 0.657 & & & \\
\hline $\begin{array}{l}\text { The travel contract clearly states the self- } \\
\text { financed items. }\end{array}$ & & & 0.816 & 0.112 & 8.877 & \\
\hline Tourism products are clearly priced. & & & 0.635 & 0.139 & 9.129 & \\
\hline Fulfilling tourism contracts (FTC) & 0.844 & 0.580 & & & & 0.838 \\
\hline $\begin{array}{l}\text { The tourism products provided are consistent } \\
\text { with the signed contract. }\end{array}$ & & & 0.628 & & & \\
\hline $\begin{array}{l}\text { Tourism enterprises or service staff does not } \\
\text { arbitrarily suspend service activities. }\end{array}$ & & & 0.660 & 0.122 & 9.904 & \\
\hline $\begin{array}{l}\text { Tourism enterprises or service staff does not } \\
\text { force tourists to consume. }\end{array}$ & & & 0.839 & 0.156 & 11.775 & \\
\hline $\begin{array}{l}\text { Tourism enterprises or service staff does not } \\
\text { deceive tourists. }\end{array}$ & & & 0.887 & 0.146 & 12.086 & \\
\hline Travel feedback processing (TFP) & 0.898 & 0.692 & & & & 0.887 \\
\hline The tourism feedback channel is unobstructed. & & & 0.635 & & & \\
\hline $\begin{array}{l}\text { Tourism enterprises can quickly resolve my } \\
\text { complaints according to the law. }\end{array}$ & & & 0.825 & 0.092 & 12.252 & \\
\hline $\begin{array}{l}\text { Regulatory authorities deal with my complaints } \\
\text { quickly. }\end{array}$ & & & 0.919 & 0.092 & 13.178 & \\
\hline $\begin{array}{l}\text { Regulatory authorities quickly resolve my } \\
\text { complaints according to the law. }\end{array}$ & & & 0.916 & 0.095 & 13.161 & \\
\hline Regulatory oversight (RO) & 0.887 & 0.616 & & & & 0.881 \\
\hline $\begin{array}{l}\text { The market transaction in the tourism industry is } \\
\text { fair. }\end{array}$ & & & 0.587 & & & \\
\hline $\begin{array}{l}\text { The laws and regulations protecting tourists are } \\
\text { perfect. }\end{array}$ & & & 0.835 & 0.136 & 11.153 & \\
\hline $\begin{array}{l}\text { The institutions regulating the tourism market } \\
\text { are sound. }\end{array}$ & & & 0.918 & 0.141 & 11.723 & \\
\hline $\begin{array}{l}\text { Regulatory authorities ensure the tourism market } \\
\text { is regulated. }\end{array}$ & & & 0.868 & 0.130 & 11.407 & \\
\hline Regulatory authorities protect tourists' interests. & & & 0.665 & 0.136 & 9.614 & \\
\hline
\end{tabular}


Table 7. Correlations and Square Roots of Average Variance Extracted (AVE) $(\mathrm{N}=319)$.

\begin{tabular}{lllllll}
\hline & AVE & TIA & TCC & FTC & TCT & RO \\
\hline TIA & 0.496 & $\mathbf{0 . 7 0 4}$ & & & & \\
TCC & 0.500 & 0.472 & $\mathbf{0 . 7 0 7}$ & & & \\
FTC & 0.580 & 0.670 & 0.382 & $\mathbf{0 . 7 6 2}$ & & \\
TCT & 0.692 & 0.417 & 0.229 & 0.405 & $\mathbf{0 . 8 3 2}$ & \\
RO & 0.616 & 0.344 & 0.214 & 0.347 & 0.520 & $\mathbf{0 . 7 8 5}$ \\
\hline
\end{tabular}

Note: The diagonal elements are the square roots of the AVE. Numbers below the diagonal are the correlations between the dimensions $(\mathrm{p}<0.05)$. 


\section{Supplementary material for online publication}

\section{Appendix A. Questionnaire}

\section{How to evaluate tourism market regulation?}

\section{An investigation of tourist market regulation from tourists' perspective}

Thank you for participating in this survey. Please make an objective analysis of the tourism market regulation based on your latest travel experience. This questionnaire is completely anonymous and only used for academic research.

\section{Section I. Screening question}

Have you had a travel experience in the past 12 months?

$\square$ Yes $\quad \square$ No (Stop the survey)

\section{Section II. Travel details}

The area where you traveled most recently (possible answers include 34 provincial-level administrative regions in China and abroad).

The type of tourism enterprises that recently provided you with products or services (Multiple choice questions)

$\square$ Offline travel agency $\square$ Online travel enterprise $\quad \square$ Tourist attractions $\quad \square$ Hotel $\square$ Others

\section{Section III. Measurement items}

$1=$ Strongly Disagree $; 4=$ Neutral $; 7=$ Strongly Agree

\begin{tabular}{|l|l|l|l|l|l|l|l|}
\hline 1. Tourism information is transparent. & 1 & 2 & 3 & 4 & 5 & 6 & 7 \\
\hline 2. Tourism information is true. & 1 & 2 & 3 & 4 & 5 & 6 & 7 \\
\hline
\end{tabular}




\begin{tabular}{|c|c|c|c|c|c|c|c|}
\hline 3. There is no misleading tourism information. & 1 & 2 & 3 & 4 & 5 & 6 & 7 \\
\hline 4. Tourism information does not violate laws and regulations. & 1 & 2 & 3 & 4 & 5 & 6 & 7 \\
\hline 5. The travel contract is signed with the consent of both parties. & 1 & 2 & 3 & 4 & 5 & 6 & 7 \\
\hline 6. The travel contract clauses are specific. & 1 & 2 & 3 & 4 & 5 & 6 & 7 \\
\hline 7. The travel contract clearly states the included product. & 1 & 2 & 3 & 4 & 5 & 6 & 7 \\
\hline 8. The travel contract clearly states the self-financed items. & 1 & 2 & 3 & 4 & 5 & 6 & 7 \\
\hline 9. Tourism products are clearly priced. & 1 & 2 & 3 & 4 & 5 & 6 & 7 \\
\hline 10. There are no overruling clauses that infringe on tourists' interests. & 1 & 2 & 3 & 4 & 5 & 6 & 7 \\
\hline $\begin{array}{l}\text { 11. Tourism enterprises perform their obligations according to the signed } \\
\text { contract. }\end{array}$ & 1 & 2 & 3 & 4 & 5 & 6 & 7 \\
\hline 12. The tourism products provided are consistent with the signed contract. & 1 & 2 & 3 & 4 & 5 & 6 & 7 \\
\hline 13. Travel services meet service standards agreed on by both parties. & 1 & 2 & 3 & 4 & 5 & 6 & 7 \\
\hline $\begin{array}{l}\text { 14. Tourism enterprises or service staff does not arbitrarily suspend service } \\
\text { activities. }\end{array}$ & 1 & 2 & 3 & 4 & 5 & 6 & 7 \\
\hline 15. Tourism enterprises or service staff does not force tourists to consume. & 1 & 2 & 3 & 4 & 5 & 6 & 7 \\
\hline 16. Tourism enterprises or service staff does not deceive tourists. & 1 & 2 & 3 & 4 & 5 & 6 & 7 \\
\hline 17. Tourism feedback channel is unobstructed. & 1 & 2 & 3 & 4 & 5 & 6 & 7 \\
\hline 18. Tourism complaint-handling procedures are regulated. & 1 & 2 & 3 & 4 & 5 & 6 & 7 \\
\hline 19. Tourism enterprises give positive feedback on issues I raise. & 1 & 2 & 3 & 4 & 5 & 6 & 7 \\
\hline $\begin{array}{l}\text { 20. Tourism enterprises quickly resolve my complaints according to the } \\
\text { law. }\end{array}$ & 1 & 2 & 3 & 4 & 5 & 6 & 7 \\
\hline 21. Regulatory authorities deal with my complaints quickly. & 1 & 2 & 3 & 4 & 5 & 6 & 7 \\
\hline $\begin{array}{l}\text { 22. Regulatory authorities quickly resolved my complaints according to the } \\
\text { law. }\end{array}$ & 1 & 2 & 3 & 4 & 5 & 6 & 7 \\
\hline 23. The market transaction in tourism industry is fair. & 1 & 2 & 3 & 4 & 5 & 6 & 7 \\
\hline 24. The laws and regulations protecting tourists are perfect. & 1 & 2 & 3 & 4 & 5 & 6 & 7 \\
\hline 25. The institutions regulating the tourism market are sound. & 1 & 2 & 3 & 4 & 5 & 6 & 7 \\
\hline 26. Regulatory authorities ensure the tourism market is regulated. & 1 & 2 & 3 & 4 & 5 & 6 & 7 \\
\hline 27. Regulatory authorities protect tourists' interests. & 1 & 2 & 3 & 4 & 5 & 6 & 7 \\
\hline
\end{tabular}

\section{Section IV. Demographic Information}

1. Gender: $\square$ Male $\square$ Female

2. Age: $\square 18-25$ years old $\quad \square 26-30 \quad \square 31-40 \quad \square 41-50 \quad \square 51-60 \quad \square 61$ years or older

3. Highest level of education:

$\square$ Senior high school or below $\square$ Junior college $\quad \square$ Undergraduate $\square$ Postgraduate or above

4. Occupation: $\square$ Government staff/civil servant $\square$ Enterprise staff $\square$ Teacher

$\square$ Private business owner $\quad \square$ Student $\quad \square$ Freelancer $\quad \square$ Retired $\quad \square$ Other

5. Which province/city or area are you living in? $\square$

Thank you very much for your participation! 


\section{Appendix B. Questionnaire}

Section III. Measurement items (The other sections are consistent with the EFA questionnaire.)

1 = Strongly Disagree $; 4=$ Neutral $; 7=$ Strongly Agree

\begin{tabular}{|c|c|c|c|c|c|c|c|}
\hline 1. Tourism information is transparent & 1 & 2 & 3 & 4 & 5 & 6 & 7 \\
\hline 2. Tourism information is true & 1 & 2 & 3 & 4 & 5 & 6 & 7 \\
\hline 3. There is no misleading tourism information & 1 & 2 & 3 & 4 & 5 & 6 & 7 \\
\hline 4. Tourism information does not violate laws and regulations & 1 & 2 & 3 & 4 & 5 & 6 & 7 \\
\hline 5. The travel contract is signed with the consent of both parties & 1 & 2 & 3 & 4 & 5 & 6 & 7 \\
\hline 6. The travel contract clearly states the included product & 1 & 2 & 3 & 4 & 5 & 6 & 7 \\
\hline 7. The travel contract clearly states the self-financed items & 1 & 2 & 3 & 4 & 5 & 6 & 7 \\
\hline 8. Tourism products are clearly priced & 1 & 2 & 3 & 4 & 5 & 6 & 7 \\
\hline 9. The tourism products provided are consistent with the signed contract & 1 & 2 & 3 & 4 & 5 & 6 & 7 \\
\hline 10. Travel services meet service standards agreed by both parties & 1 & 2 & 3 & 4 & 5 & 6 & 7 \\
\hline $\begin{array}{l}\text { 11. Tourism enterprises or service staff do not arbitrarily suspend service } \\
\text { activities }\end{array}$ & 1 & 2 & 3 & 4 & 5 & 6 & 7 \\
\hline 12. Tourism enterprises or service staff do not force tourists to consume & 1 & 2 & 3 & 4 & 5 & 6 & 7 \\
\hline 13. Tourism enterprises or service staff do not deceive tourists & 1 & 2 & 3 & 4 & 5 & 6 & 7 \\
\hline 14. Tourism feedback channel is unobstructed & 1 & 2 & 3 & 4 & 5 & 6 & 7 \\
\hline 15. Tourism complaints handling procedures are regulated & 1 & 2 & 3 & 4 & 5 & 6 & 7 \\
\hline $\begin{array}{l}\text { 16. Tourism enterprises quickly resolve my complaints according to the } \\
\text { law }\end{array}$ & 1 & 2 & 3 & 4 & 5 & 6 & 7 \\
\hline 17. Regulatory authorities deal with my complaints quickly & 1 & 2 & 3 & 4 & 5 & 6 & 7 \\
\hline $\begin{array}{l}\text { 18. Regulatory authorities quickly resolved my complaints according to the } \\
\text { law }\end{array}$ & 1 & 2 & 3 & 4 & 5 & 6 & 7 \\
\hline 19. The market transaction in tourism industry is fair & 1 & 2 & 3 & 4 & 5 & 6 & 7 \\
\hline 20. The laws and regulations protecting tourists are perfect & 1 & 2 & 3 & 4 & 5 & 6 & 7 \\
\hline 21. The institutions regulating the tourism market are sound & 1 & 2 & 3 & 4 & 5 & 6 & 7 \\
\hline 22. Regulatory authorities ensure the tourism market is regulated & 1 & 2 & 3 & 4 & 5 & 6 & 7 \\
\hline 23. Regulatory authorities protect tourists' interests & 1 & 2 & 3 & 4 & 5 & 6 & 7 \\
\hline
\end{tabular}




\section{您怎么评价旅游市场秩序？游客视角的旅游市场秩序调查}

尊敬的先生/女士:

您好！首先非常感谢您在百忙之中填写问卷。请您根据最近一次的旅游经历对旅游市场秩序状 况做出客观评价，按同意程度由低到高依次为：1-非常不同意、2-不同意、3-有些不同意、4-一 般、5-有些同意、6-同意、7-非常同意。您的回答对本研究十分重要，本问卷完全匿名且仅用于学 术研究, 我们对您的支持表示衰心感谢!

\section{第 1 部分：篮选问题}

您是否有过旅游的经历？【】
A. 有
B.没有

\section{第 2 部分：旅游信息}

I. 您最近旅游的目的地（中国 34 个省级行政区域或其他国家和地区）。

II. 最近一次为您提供产品或服务的旅游企业类型【】（旅游企业指旅行社、景区以及为旅游者提 供交通、住宿、餐饮、购物、娱乐等服务的企业。）
A. 线下旅行社
B. 在线旅游企业
C.景区
D.酒店
E. 其他

1 = 非常不同意; $4=$ 一般; $7=$ 非常同意

\begin{tabular}{|l|l|l|l|l|l|l|l|}
\hline 1.旅游信息是公开透明的 & 1 & 2 & 3 & 4 & 5 & 6 & 7 \\
\hline 2.旅游信息是真实的 & 1 & 2 & 3 & 4 & 5 & 6 & 7 \\
\hline 3.无误导性的旅游信息 & 1 & 2 & 3 & 4 & 5 & 6 & 7 \\
\hline 4.旅游信息不违反法律法规 & 1 & 2 & 3 & 4 & 5 & 6 & 7 \\
\hline 5.旅游合同是在双方同意下形成的 & 1 & 2 & 3 & 4 & 5 & 6 & 7 \\
\hline 6.旅游合同的条款约定明确 & 1 & 2 & 3 & 4 & 5 & 6 & 7 \\
\hline 7.旅游合同中明确说明了所含产品项目 & 1 & 2 & 3 & 4 & 5 & 6 & 7 \\
\hline 8.旅游合同中明确说明了自费项目 & 1 & 2 & 3 & 4 & 5 & 6 & 7 \\
\hline 9.旅游产品是明码标价的 & 1 & 2 & 3 & 4 & 5 & 6 & 7 \\
\hline 10. 旅游合同中无侵害旅游者权益的霸王条款 & 1 & 2 & 3 & 4 & 5 & 6 & 7 \\
\hline 11.旅游企业能够按照签订的合同履行义务 & 1 & 2 & 3 & 4 & 5 & 6 & 7 \\
\hline 12.旅游企业提供的旅游产品与合同是一致的 & 1 & 2 & 3 & 4 & 5 & 6 & 7 \\
\hline
\end{tabular}




\begin{tabular}{|c|c|c|c|c|c|c|c|}
\hline 13. 旅游服务符合双方约定的服务标准和规范 & 1 & 2 & 3 & 4 & 5 & 6 & 7 \\
\hline 14.旅游企业或服务人员不擅自中止服务活动 & 1 & 2 & 3 & 4 & 5 & 6 & 7 \\
\hline 15. 旅游企业或服务人员无强制游客消费的行为 & 1 & 2 & 3 & 4 & 5 & 6 & 7 \\
\hline 16.旅游企业或服务人员不欺诈游客 & 1 & 2 & 3 & 4 & 5 & 6 & 7 \\
\hline 17.旅游投诉反馈渠道是通畅的 & 1 & 2 & 3 & 4 & 5 & 6 & 7 \\
\hline 18.旅游投诉反馈处理程序是规范的 & 1 & 2 & 3 & 4 & 5 & 6 & 7 \\
\hline 19. 旅游企业能够对我提出的问题做出积极反馈 & 1 & 2 & 3 & 4 & 5 & 6 & 7 \\
\hline 20.旅游企业能够依法快速解决我的投诉 & 1 & 2 & 3 & 4 & 5 & 6 & 7 \\
\hline 21. 监管部门能够对我的投诉做出迅速反馈 & 1 & 2 & 3 & 4 & 5 & 6 & 7 \\
\hline 22.监管部门能够依法快速解决我的投诉 & 1 & 2 & 3 & 4 & 5 & 6 & 7 \\
\hline 23.旅游行业的市场交易是公平公正的 & 1 & 2 & 3 & 4 & 5 & 6 & 7 \\
\hline 24.保护旅游者的相关法律法规是完善的 & 1 & 2 & 3 & 4 & 5 & 6 & 7 \\
\hline 25.规范旅游市场运行的相关制度是健全的 & 1 & 2 & 3 & 4 & 5 & 6 & 7 \\
\hline 26.监管部门确保旅游市场是规范有序的 & 1 & 2 & 3 & 4 & 5 & 6 & 7 \\
\hline 27.监管部门注重旅游者权益的保护 & 1 & 2 & 3 & 4 & 5 & 6 & 7 \\
\hline
\end{tabular}

\section{人口统计学信息}

1. 您的性别: [单选题]*
口男
口女

2. 您的年龄段: [单选题]*

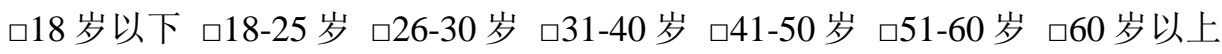

3. 您的学历: [单选题] *

口高中及以下 口大专 口本科 硕士 㗘士

4. 您目前从事的职业: [单选题] *

口政府机关/事业单位职员 口企业/公司职员 口教育工作者 口私营业主/个体户口农民口学生 口自由 职业者 口离退休人员 口其他

5. 您所在的省份或地区:

非常感谢您的支持与参与！ 


\begin{tabular}{|c|c|c|c|c|c|c|c|c|c|}
\hline & $\mathrm{N}$ & Minimum & Maximum & Mean & $\begin{array}{l}\text { Std. } \\
\text { Deviation }\end{array}$ & Skewness & & Kurtosis & \\
\hline & Statistic & Statistic & Statistic & Statistic & Statistic & Statistic & $\begin{array}{l}\text { Std. } \\
\text { Error }\end{array}$ & Statistic & $\begin{array}{l}\text { Std. } \\
\text { Error }\end{array}$ \\
\hline Q1 & 415 & 1 & 7 & 4.22 & 1.505 & -0.168 & 0.12 & -0.737 & 0.239 \\
\hline Q2 & 415 & 1 & 7 & 4.51 & 1.364 & -0.159 & 0.12 & -0.764 & 0.239 \\
\hline Q3 & 415 & 1 & 7 & 3.96 & 1.555 & 0.188 & 0.12 & -0.81 & 0.239 \\
\hline Q4 & 415 & 1 & 7 & 4.94 & 1.485 & -0.576 & 0.12 & -0.558 & 0.239 \\
\hline Q5 & 415 & 1 & 7 & 5.5 & 1.196 & -1.034 & 0.12 & 0.838 & 0.239 \\
\hline Q6 & 415 & 1 & 7 & 4.42 & 1.45 & -0.118 & 0.12 & -0.726 & 0.239 \\
\hline Q7 & 415 & 1 & 7 & 4.68 & 1.445 & -0.311 & 0.12 & -0.792 & 0.239 \\
\hline Q8 & 415 & 1 & 7 & 4.69 & 1.413 & -0.355 & 0.12 & -0.727 & 0.239 \\
\hline Q9 & 415 & 1 & 7 & 4.63 & 1.46 & -0.268 & 0.12 & -0.789 & 0.239 \\
\hline Q10 & 415 & 1 & 7 & 4.33 & 1.554 & -0.15 & 0.12 & -0.734 & 0.239 \\
\hline Q11 & 415 & 1 & 7 & 4.73 & 1.329 & -0.361 & 0.12 & -0.26 & 0.239 \\
\hline Q12 & 415 & 1 & 7 & 4.54 & 1.32 & -0.158 & 0.12 & -0.478 & 0.239 \\
\hline Q13 & 415 & 1 & 7 & 4.61 & 1.301 & -0.178 & 0.12 & -0.401 & 0.239 \\
\hline Q14 & 415 & 1 & 7 & 4.89 & 1.325 & -0.521 & 0.12 & -0.178 & 0.239 \\
\hline Q15 & 415 & 1 & 7 & 4.16 & 1.673 & -0.081 & 0.12 & -0.941 & 0.239 \\
\hline Q16 & 415 & 1 & 7 & 4.19 & 1.551 & 0.047 & 0.12 & -0.747 & 0.239 \\
\hline Q17 & 415 & 1 & 7 & 3.85 & 1.411 & 0.047 & 0.12 & -0.495 & 0.239 \\
\hline Q18 & 415 & 1 & 7 & 3.99 & 1.27 & -0.103 & 0.12 & -0.374 & 0.239 \\
\hline Q19 & 415 & 1 & 7 & 4.07 & 1.405 & -0.001 & 0.12 & -0.241 & 0.239 \\
\hline Q20 & 415 & 1 & 7 & 3.97 & 1.386 & 0.161 & 0.12 & -0.19 & 0.239 \\
\hline Q21 & 415 & 1 & 7 & 3.94 & 1.436 & 0.083 & 0.12 & -0.333 & 0.239 \\
\hline Q22 & 415 & 1 & 7 & 3.94 & 1.443 & 0.087 & 0.12 & -0.261 & 0.239 \\
\hline Q23 & 415 & 1 & 7 & 3.83 & 1.34 & 0.089 & 0.12 & -0.346 & 0.239 \\
\hline Q24 & 415 & 1 & 7 & 3.79 & 1.422 & 0.100 & 0.12 & -0.421 & 0.239 \\
\hline Q25 & 415 & 1 & 7 & 3.74 & 1.378 & 0.036 & 0.12 & -0.431 & 0.239 \\
\hline Q26 & 415 & 1 & 7 & 3.55 & 1.345 & 0.238 & 0.12 & -0.18 & 0.239 \\
\hline Q27 & 415 & 1 & 7 & 4.11 & 1.454 & 0.062 & 0.12 & -0.341 & 0.239 \\
\hline
\end{tabular}


Appendix D. Descriptive statistics (sample for CFA)

\begin{tabular}{|c|c|c|c|c|c|c|c|c|c|}
\hline & $\mathrm{N}$ & Minimum & Maximum & Mean & $\begin{array}{l}\text { Std. } \\
\text { Deviation }\end{array}$ & Skewness & & Kurtosis & \\
\hline & Statistic & Statistic & Statistic & Statistic & Statistic & Statistic & $\begin{array}{l}\text { Std. } \\
\text { Error }\end{array}$ & Statistic & $\begin{array}{l}\text { Std. } \\
\text { Error }\end{array}$ \\
\hline Q1 & 319 & 1 & 7 & 4.38 & 1.237 & -0.064 & 0.137 & -0.368 & 0.272 \\
\hline Q2 & 319 & 1 & 7 & 4.46 & 1.233 & 0.010 & 0.137 & -0.672 & 0.272 \\
\hline Q3 & 319 & 1 & 7 & 3.88 & 1.333 & 0.356 & 0.137 & -0.291 & 0.272 \\
\hline Q4 & 319 & 2 & 7 & 5.21 & 1.249 & -0.621 & 0.137 & -0.262 & 0.272 \\
\hline Q5 & 319 & 1 & 7 & 5.67 & 1.028 & -1.131 & 0.137 & 2.083 & 0.272 \\
\hline Q6 & 319 & 1 & 7 & 4.79 & 1.342 & -0.279 & 0.137 & -0.490 & 0.272 \\
\hline Q7 & 319 & 1 & 7 & 4.72 & 1.380 & -0.426 & 0.137 & -0.297 & 0.272 \\
\hline Q8 & 319 & 1 & 7 & 4.79 & 1.393 & -0.407 & 0.137 & -0.366 & 0.272 \\
\hline Q9 & 319 & 1 & 7 & 4.58 & 1.132 & -0.279 & 0.137 & -0.253 & 0.272 \\
\hline Q10 & 319 & 2 & 7 & 4.83 & 1.143 & -0.357 & 0.137 & -0.314 & 0.272 \\
\hline Q11 & 319 & 1 & 7 & 4.95 & 1.300 & -0.659 & 0.137 & 0.091 & 0.272 \\
\hline Q12 & 319 & 1 & 7 & 4.32 & 1.554 & -0.226 & 0.137 & -0.804 & 0.272 \\
\hline Q13 & 319 & 1 & 7 & 4.29 & 1.415 & -0.026 & 0.137 & -0.648 & 0.272 \\
\hline Q14 & 319 & 1 & 7 & 3.96 & 1.400 & 0.148 & 0.137 & -0.514 & 0.272 \\
\hline Q15 & 319 & 1 & 7 & 4.14 & 1.215 & 0.039 & 0.137 & -0.174 & 0.272 \\
\hline Q16 & 319 & 1 & 7 & 3.83 & 1.213 & 0.175 & 0.137 & 0.022 & 0.272 \\
\hline Q17 & 319 & 1 & 7 & 3.84 & 1.173 & 0.073 & 0.137 & 0.270 & 0.272 \\
\hline Q18 & 319 & 1 & 7 & 3.89 & 1.215 & 0.095 & 0.137 & 0.179 & 0.272 \\
\hline Q19 & 319 & 1 & 7 & 3.98 & 1.169 & 0.019 & 0.137 & -0.043 & 0.272 \\
\hline Q20 & 319 & 1 & 7 & 3.75 & 1.251 & 0.048 & 0.137 & -0.286 & 0.272 \\
\hline Q21 & 319 & 1 & 7 & 3.65 & 1.240 & 0.101 & 0.137 & -0.131 & 0.272 \\
\hline Q22 & 319 & 1 & 7 & 3.52 & 1.170 & 0.109 & 0.137 & -0.092 & 0.272 \\
\hline Q23 & 319 & 1 & 7 & 4.11 & 1.350 & 0.241 & 0.137 & -0.162 & 0.272 \\
\hline
\end{tabular}

